\title{
ESTIMATIVA DA PARTICIPAÇÃO DO GENOMA DE Bos taurus NO REBANHO NELORE
}

\section{Paula Ripamonte}

Dissertação de Mestrado apresentada à Comissão de Pós-Graduação da Faculdade de Zootecnia e Engenharia de Alimentos da USP em 22 de maio de 2002, como parte dos requisitos para a obtenção do Título de Mestre em Zootecnia, na área de Concentração: Qualidade e Produtividade Animal.

Orientador: Prof. Dr. Flávio Vieira Meirelles 


\section{FICHA CATALOGRÁFICA}

preparada pela

Biblioteca da Faculdade de Zootecnia e Engenharia de Alimentos da Universidade de São Paulo

Ripamonte, Paula.

R588e Estimativa da participação do genoma de Bos taurus no rebanho Nelore / Paula Ripamonte. -- Pirassununga, 2002. p.57

Dissertação (Mestrado) -- Faculdade de Zootecnia e

Engenharia de Alimentos - Universidade de São Paulo, 2002.

Departamento de Ciências Básicas

Área de concentração: Qualidade e Produtividade Animal

Orientador: Prof. Dr. Flávio Vieira Meirelles.

Unitermos: 1. Bovinos 2. Microssatélites 3. DNA mitocondrial 4. DNA satélite 5. Bos taurus 6. Bos indicus I. Título. 


$$
\begin{aligned}
& \text { Ao meu noivo, Luis } \\
& \text { Gustavo, responsável pelas } \\
& \text { mudanças em minha vida, uma } \\
& \text { das quais culmina na realização } \\
& \text { deste trabalho. Dedico. }
\end{aligned}
$$


Deus, en vos agradeço Senhor, por me conceder a vida e a oportunidade de estudá-la, tentando entendê-la. 


\section{AGRADECIMENTO ESPECIAL}

Ao men orientador, Ilávio, que com sua paciência e seriedade me acolhen e acrediton que en pudesse trabalhar ao sen lado, o que se constituin numa tarefa muito agradável, na qual permaneci, sem encontrar palauras suficientes para demonstrar minha gratidão... Espero um dia, poder retribuir a confiança que em mim foi depositada e acreditar, para sempre, em nossa amizade. 


\section{AGRADECIMENTOS}

Aos meus pais Francisco e Fernanda e, também às minhas irmãs, Camila e Estela, ao cunhado Washington, pelo incentivo e incondicional apoio de todos os momentos. A certeza da nossa união constante e do amor que ampara meus passos, estarão sempre assegurando-me os ideais.

Aos meus avós, Biná e Lavínia; Diva e Antônio, grandes incentivadores, cujas orações fortaleceram minhas escolhas e carreira profissional, dos quais sempre sinto a presença iluminando meu caminho.

A todos os integrantes do Laboratório de Morfo-fisiologia Molecular e Desenvolvimento, pelas gentilezas e companheirismo, colaboraram para a realização deste trabalho. A Giovana, Yeda, Raquel, Mariney, Sheila, Mariana, Kátia, Marcos e Alexandre, o meu carinho e gratidão.

Aos "flutuantes" (estagiários) do Laboratório pelo auxílio e convivência durante suas estadas.

Ao Professor e amigo José Bento Sterman Ferraz, a quem respeitosamente admiro, um dos responsáveis pelas mudanças de rumo que ocorreram em minha vida e, que nos momentos mais difíceis, me apresentou soluções e oportunidades, acreditando no desenvolvimento de minhas capacidades. Ao insigne mestre sou infinitamente grata.

A todos do GMA, principalmente ao Prof. Dr. Joanir Pereira Eler, pessoas que de alguma maneira contribuíram para meu desenvolvimento acadêmico e pessoal. 
Aos amigos e colegas de pós-graduação, pela convivência que foi imprescindível em minha formação pessoal e profissional.

A todos do Laboratório de Micromanipulação de Embriões e Molecular da FMRP, USP, principalmente ao Prof. Dr. Raysildo Barbosa Lôbo, pelas deferências com as quais fui recebida e pelo treinamento que se constituiu fundamental para que se desenvolvesse este trabalho. Agradecimentos especiais a Vanderli e ao Reginaldo que guiaram meus primeiros passos nesta nova área.

Ao Artur Jordão de Magalhães Rosa, pela contribuição na fase inicial do desenvolvimento deste trabalho.

Ao Prof. Dr. Luiz Lehmann Coutinho e seus técnicos pelo apoio no seqüenciamento do DNA satélite aqui descrito.

As minhas companheiras de morada, Juliana e Marcinha, amigas para todas as horas, agradeço por tudo que partilhamos.

A Profa. Dra. Maria de Fátima que me recebeu, depois me deixou partir, para que outros caminhos fossem descobertos e pelos quais me conduzi, sem ter até agora, o que faço humildemente neste instante, apresentado a ela meu reconhecimento.

Aos funcionários da FZEA, pelo inestimável apoio nas atividades acadêmicas, principalmente aos funcionários da Biblioteca pelo auxílio na revisão deste trabalho.

A FAPESP pelo indispensável apoio financeiro que possibilitou o meu aprimoramento acadêmico e também o desenvolvimento deste trabalho. 
SUMÁRIO

Página

LISTA DE FIGURAS............................................................... ii

LISTA DE TABELAS............................................................... v

LISTA DE ABREVIATURAS......................................................... vii

LISTA DE SÍMBOLOS..................................................................... viii

RESUMO

ABSTRACT

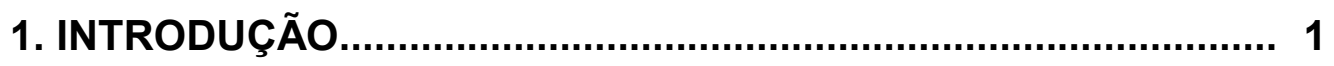

2. REVISÃO BIBLIOGRÁFICA.................................................. 4

2.1. Filogenia dos bovinos........................................................ 4

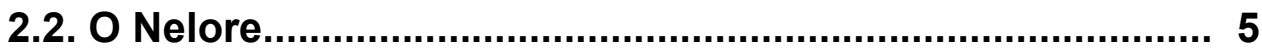

2.3. DNA mitocondrial............................................................... 6

2.4. Marcadores nucleares...................................................... 7

2.4.1. DNA microssatélite.................................................... 7

2.4.2. DNA satélite....................................................... 10

3. MATERIAL E MÉTODOS....................................................... 14

3.1. Local do experimento...................................................... 14

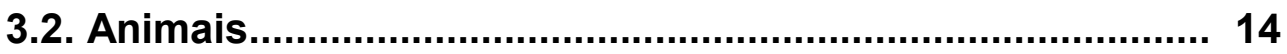

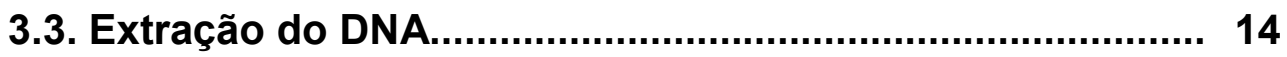

3.4. DNA mitocondrial (mtDNA) .............................................. 15

3.5. Amplificação dos microssatélites....................................... 16

3.6. PCR RFLP do satélite 1711b............................................ 21

3.7. Sequenciamento do DNA satélite 1711b.......................... 22

3.8. Análise estatística......................................................... 23

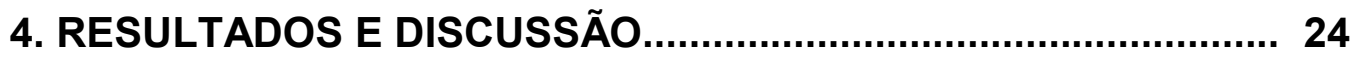

4.1. DNA mitocondrial e microssatélites................................... 24

4.2. DNA satélite 1711b..................................................... 41

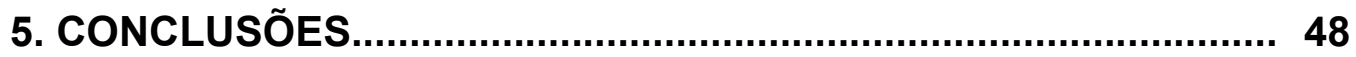

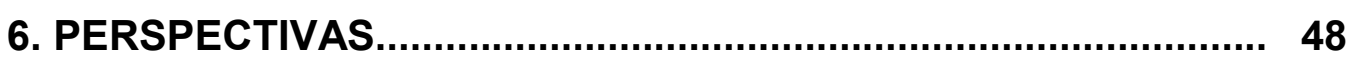

7. REFERÊNCIAS BIBLIOGRÁFICAS........................................ 49 


\section{LISTA DE FIGURAS}

FIGURA 1 - Reconstrução filogenética com base em marcadores microssatélites e DNA mitocondrial (adaptado de BRADLEY et al., 1998)................................................

FIGURA 2 - Esquema do DNA mitocondrial de Bos indicus. 16

FIGURA 3 - Seqüência de nucleotídeos dos fragmentos microssatélites amplificados (Oligonucleotídeos iniciadores em itálico).

FIGURA 4 - Esquema dos cromossomos determinando a localização dos microssatélites utilizados

FIGURA 5 - Fragmento de 875 pb amplificado do DNA satélite $1711 \mathrm{~b}$ de Bos taurus (oligonucleotídeos iniciadores em negrito e itálico e sítios de restrição sublinhados)...

FIGURA 6 - Resultado da digestão com enzima de restrição Hind III na análise do DNA mitocondrial de bovinos da raça Nelore. Animais com mtDNA Bos indicus (i) e animais com mtDNA Bos taurus ( $\mathrm{t}$ )

FIGURA 7 - Freqüência dos alelos amplificados do microssatélite ETH225, em animais da raça Nelore classificados com base no mtDNA em Bos taurus e Bos indicus.

FIGURA 8 - Freqüência dos alelos amplificados do microssatélite HEL1, em animais da raça Nelore classificados com base no mtDNA em Bos taurus e Bos indicus. 
FIGURA 9 - Freqüência dos alelos amplificados do microssatélite HEL9, em animais da raça Nelore classificados com base no mtDNA em Bos taurus e Bos indicus.

FIGURA 10 - Freqüência dos alelos amplificados do microssatélite ILSTS005, em animais da raça Nelore classificados com base no mtDNA em Bos taurus e Bos indicus.

FIGURA 11 - Freqüência dos alelos amplificados do microssatélite INRA063, em animais da raça Nelore classificados com base no mtDNA em Bos taurus e Bos indicus.

FIGURA 12 - Polimorfismo do microssatélite ETH225 em animais da raça Nelore. Gel de Poliacrilamida desnaturante $6 \%$, primers marcados com FAM

FIGURA 13 - Intensidade de branco da área de migração dos fragmentos de DNA do microssatélite HEL9. Na figura 13a está representado um animal de genótipo 153159 e na figura $13 \mathrm{~b}$ um animal de genótipo 151-157 .... 33

FIGURA 14 - Haplótipos para o locus microssatélite ETH225 encontrados na raça Nelore.

FIGURA 15 - Haplótipos para o locus microssatélite HEL1 encontrados na raça Nelore.

FIGURA 16 - Haplótipos para o locus microssatélite HEL9 encontrados na raça Nelore. 
FIGURA 17 - Haplótipos para o locus microssatélite ILSTS005 encontrados na raça Nelore.

FIGURA 18 - Haplótipos para o locus microssatélite INRA063 encontrados na raça Nelore.

FIGURA 19 - Dendograma criado a partir dos dados de distância genética calculados dos microssatélites ETH225, HEL1, HEL9 e ILSTS005 para a população de Europeus e Nelore mtDNA taurus e indicus.

FIGURA 20 - Eletroferograma do DNA Satélite seqüenciado a partir do fragmento do DNA amplificado pela PCR. O quadro indica o sítio de restrição da enzima Msp I em um animal portador do padrão de restrição $A B$. A seta indica o nucleotídeo polimórfico

FIGURA 21 - Genótipos encontrados para o DNA Satélite 1711b após digestão com a enzima Msp I. Figura 21a representa animais da raça Nelore e a figura 21b representa animais europeus

FIGURA 22 - Freqüência dos genótipos encontrados para o DNA Satélite $1711 \mathrm{~b}$ após digestão com a enzima Msp I...... 45 


\section{LISTA DE TABELAS}

TABELA 1 - Seqüência dos oligonucleotídeos iniciadores para amplificação dos microssatélites e sua localização cromossômica (cr).

TABELA 2 - Programa utilizado na amplificação dos Microssatélites.

TABELA 3 - Temperaturas de anelamento dos primers utilizadas na amplificação dos fragmentos microssatélites

TABELA 4 - Programa utilizado na amplificação do Satélite $1711 b$.

TABELA 5 - Possíveis fragmentos esperados após digestão do DNA satélite $1711 \mathrm{~b}$

TABELA 6 - Freqüência dos alelos dos cinco loci microssatélites estudados na raça Nelore, para animais mtDNA indicus e taurus.

TABELA 7 - Valores médios da diversidade gênica e Heterozigosidade para as três populações analisadas, animais de origem européia e da raça Nelore mtDNA taurus e indicus.

TABELA 8 - Diversidade gênica e Heterozigosidade para cada microssatélite nas três populações analisadas, animais de origem européia e da raça Nelore mtDNA taurus e indicus. 
TABELA 9 - Freqüência dos haplótipos dos cinco microsatélites estudados na raça Nelore, para animais mtDNA indicus e taurus.

TABELA 10 - Resultados da variância por locus em cada população

TABELA 11 - Valores de RHO e P para os componentes de variância nas três populações analisadas.

TABELA 12 - Valores de RHO e P para os loci microssatélites nas três populações analisadas.

TABELA 13 - Valores de distância genética $(\delta \mu)^{2}$ para as populações analisadas

TABELA 14 - Presença (+) ou ausência (-) do sítio de restrição para a enzima Msp I no DNA satélite $1711 \mathrm{~b}$ em animais taurinos e zebuínos 


\section{LISTA DE ABREVIATURAS}

mtDNA - DNA mitocondrial

PCR - "Reaction Chain Polymerase" (Reação em Cadeia da Polimerase)

RFLP - "Restriction Fragment Lenght Polymorphism" (Polimorfismo no Comprimento do Fragmento de Restrição)

stDNA - DNA satélite

dATP - Deoxinucleosídeo adenosina trifosfato

dTTP - Deoxinucleosídeo timina trifosfato

dCTP - Deoxinucleosídeo citosina trifosfato

dGTP - Deoxinucleosídeo guanina trifosfato

EDTA - Ácido Etileno diamino tetra acético

TBE - Tris Borato EDTA

RST - R de Slatkin

$\mathrm{SAS}^{\circledR}$ - Statistical Analysis System 


\section{LISTA DE SÍMBOLOS}

$(\delta \mu)^{2}-$ Distância genética

$\phi x$ - Marcador de peso molecular originado da digestão do DNA do $\phi \times 174$ RF pela enzima Hae III 


\section{RESUMO}

\section{RIPAMONTE, P. Estimativa da participação do genoma de Bos taurus} no rebanho Nelore. Pirassununga, 2002. 57p. Dissertação (mestrado) Faculdade de Zootecnia e Engenharia de Alimentos, Universidade de São Paulo.

A espécie Bos indicus, particularmente a raça Nelore, é grande maioria no rebanho bovino da região acima do trópico no Brasil. Embora a habilidade desses animais em resistir às doenças parasitárias, condições climáticas e pastagens de baixa qualidade enalteçam a utilização em larga escala desta raça, estes animais não são considerados bons conversores de alimento e, conseqüentemente, precoces em comparação aos seus homólogos Bos taurus. Durante a formação das raças zebuínas brasileiras, houve uma participação das linhas maternas de Bos taurus, que pode ser demonstrada pela contribuição majoritária do genoma mitocondrial desta subespécie. Embora em escala muito menor, estima-se que exista também uma participação destas linhas maternas no genoma nuclear. O objetivo deste trabalho foi iniciar os estudos para estimar esta participação. Para os estudos foram utilizados 104 animais da raça Nelore e 8 animais de diferentes raças européias. Cinco regiões do DNA que produzem fragmentos microssatélites taurus/indicus específicos (HEL1, HEL9, ETH225, ILSTS005 e INRA063) foram amplificadas com a utilização de primers marcados com sondas fluorescentes. Os fragmentos foram submetidos à eletroforese em gel de poliacrilamida desnaturante $6 \%$ e visualizados após excitação com laser. No total foram encontrados 23 alelos para os microssatélites analisados o que representa uma média de 4,6+1,82 alelos por locus. Amplificou-se também uma região do DNA satélite $1711 \mathrm{~b}$ que posteriormente foi digerida com a enzima de restrição Msp I. Verificou-se a 
existência de três possíveis genótipos entre os animais Nelore mtDNA Bos taurus e mtDNABos indicus. Os animais europeus analisados apresentaram sempre o mesmo padrão de restrição. A comparação dos componentes de variância do tamanho dos alelos intra e inter população usando os fragmentos microssatélites permitem a separação dos animais Bos taurus dos animais Nelore, mas não dos Nelore de origem materna distinta. No entanto, a freqüência de alelos indicus específicos nos microssatélites e de padrões de digestão do DNA satélite também indicus específicos sugerem uma participação da ordem de aproximadamente $6 \%$ do genoma taurus na população de gado Nelore.

Palavras-chave: Bovinos, Bos indicus, Bos taurus, mtDNA, microssatélites, satélite $1711 \mathrm{~b}$. 


\begin{abstract}
RIPAMONTE, P. Bos taurus contribution in Nellore (Bos indicus) Breed.

Bos indicus specie, especially Nellore breed is responsible for the majority of Brazilian tropical herd. These animals are notably capable to endure parasite infection as well as hot weather and low quality feed. In one hand this qualities suggest the large scale application of this breed, but in other hand this same breed is well characterized as bad food converter and consequently far from having good precocity status compared with its Bos taurus homologues. It has been reported a matrilineal European participation in Zebu cattle since its introduction in American lands. This hybridization is confirmed by the majority contribution of Bos taurus mtDNA in these animals. Although in a much lower frequency, we hypothesize a Bos taurus cow participation in nuclei genome. The main aim of this work was to give the firsts steps towards the estimation of this participation. A total of 104 Nellore and 8 animals of different European breeds were used for DNA analysis. Five microsatellites fragments (HEL1, HEL9, ETH225, ILSTS005 e INRA063) were amplified applying primers with fluorescent dye. Amplified fragments were used in $6 \%$ polyacrilamide electrophoresis and visualized after laser excitation. Overall 23 alleles were detected averaging 4.6+1,82/locus. Variance components of microsatellites allele size comparisons allowed the formation of two clusters separating both subspecies. No significant variation was observed between Nellore with different maternal origins. A satellite 1711b DNA was also amplified and digested with the restriction enzyme Msp I. Three possible genotypes were identified in Nellore animals harboring $B$. taurus and $B$. indicus mtDNA. European originated animals always showed the same restriction pattern. Finally $B$. indicus specific microsatellite allele and satellite $1711 \mathrm{~b}$ digestion patterns frequency allowed the estimation of $6 \%$ of $B$. taurus contribution in purebred Nellore. These results are discussed in terms of application in cattle genetic improvement.
\end{abstract}

Key-words: Bos indicus, Bos taurus, mitochondrial DNA, microsatellites, satellite DNA $1711 \mathrm{~b}$. 


\section{INTRODUÇÃO}

Os bovinos desempenham um importante papel na economia pastoril em vários países e estima-se que deva existir, aproximadamente, 1,3 bilhões de animais por todo o mundo. O rebanho bovino brasileiro possui cerca de 157 milhões de cabeças dentre as quais estão animais de origem européia (Bos taurus), de origem zebuína (Bos indicus) e mestiços.

O Brasil é considerado um dos mais importantes centros de criação e seleção de raças zebuínas e acredita-se que $80 \%$ do rebanho brasileiro apresente alguma composição genética de zebuínos.

Os primeiros registros de importações de zebuínos para o continente Americano, datam do fim do Século XIX, e acredita-se que, durante várias importações, 7.000 animais haviam sido trazidos para a América do Sul por criadores brasileiros até os anos 60 . Embora algumas fêmeas tivessem sido incluídas nestas importações, a maioria dos animais foram machos, que em seguida foram cruzados com as vacas "nativas", de ancestrais originários da península Ibérica.

Desta forma, a população de Zebu brasileiro encontra-se subdividida em descendentes de animais de origem importada (POI), em animais que podem ter sido produzidos localmente pelo cruzamento absorvente com machos zebuínos (PO) e no rebanho comercial ou azebuado de origem desconhecida.

Meirelles et al. (1999), para testar a hipótese de genes citoplasmáticos portarem polimorfismos entre animais $\mathrm{PO}$ e $\mathrm{POI}$, verificaram que a grande maioria do zebu americano é decorrente do cruzamento absorvente de fêmeas de origem taurina portadoras de mtDNA europeu com 
machos de origem do sub-continente Indiano portadores de mtDNA do $B$. indicus.

Comprovada a participação de matriarcas $B$. taurus na população de zebuínos nacionais torna-se importante quantificar a contribuição desta espécie na formação das raças zebuínas locais. Para tanto há a necessidade de se lançar mão de marcadores nucleares, onde os genes paternos e maternos de origem $B$. taurus, diferente do mtDNA, seriam herdados de maneira mendeliana e estariam sujeitos a segregação durante as etapas sucessivas características dos cruzamentos absorventes.

Com os avanços no campo da biologia molecular, como o desenvolvimento da Reação em Cadeia da Polimerase (PCR) no início dos anos 80 , e a descoberta dos marcadores moleculares microssatélites, uma série de loci altamente polimórficos vêm sendo descritos.

Vários trabalhos envolvendo marcadores microssatélites foram reportados como geradores de fragmentos polimórficos que permitem a identificação de animais Bos indicus e Bos taurus. Sendo assim a alteração da freqüência dos haplótipos $B$. taurus em animais das raças zebuínas americanas poderiam indicar a participação dos genes europeus no genoma nuclear destes animais. A freqüência com que estes alelos são encontrados nos animais zebuínos provém então um indício da freqüência de genes $B$. taurus.

Concomitantemente, um estudo populacional permitiria deter uma estimativa da participação de animais oriundos do continente europeu no zebu americano a partir da utilização do DNA Satélite.

Recentemente, foi observado uma variação em um satélite da região centromérica que introduz um sítio de restrição em parte das seqüências de animais B. indicus (Nijman et al. 1999). Esta informação permite estimar a proporção de introgressão de genes $B$. taurus em animais isoladamente.

Sendo assim, o objetivo do presente trabalho foi dar início aos estudos para estimar a participação individual e populacional do genoma Bos taurus no zebu americano, particularmente na raça Nelore, por meio de 
cinco marcadores microssatélites e um marcador satélite com fragmentos produzidos por RFLP espécie específicos. 


\section{REVISÃO BIBLIOGRÁFICA}

\subsection{Filogenia dos Bovinos}

A Família Bovidae, especialmente a tribo Bovini, desempenha um importante papel nas sociedades desde as civilizações primitivas. Muitos esforços têm sido realizados no intuito de esclarecer as relações filogenéticas entre os gêneros desta tribo, principalmente do gênero Bos.

A sistemática e as relações evolutivas dos bovinos são muito contraditórias e as pesquisas são baseadas nas diferenças morfológicas e genéticas observadas entre as duas subespécies, o zebu com cupim (Bos indicus) e o taurino sem cupim (Bos taurus) (MacHugh et al., 1997; Bradley e Cunningham, 1999).

A nomenclatura clássica de Linneu considera os zebuínos e os taurinos como espécies distintas, sendo esta classificação apoiada em polimorfismos proteicos (Manwell e Baker, 1980), polimorfismos do cromossomo $\mathrm{Y}$ (Kieffer e Cartwrigth, 1968) e polimorfismos em microssatélites autossômicos (Machugh et al., 1997). Entretanto, baseado na plasticidade da aloenzima e a completa interfertilidade entre Bos indicus e Bos taurus, muitos autores consideram-nas como subespécies.

Em relação à origem destes grupos, vários autores sugerem que as raças de bovinos presentes atualmente descendem de um único ancestral selvagem, o Auroque (Bos primigenius), domesticado durante a fase Neolítica (Loftus et al., 1994a e b). Uma outra hipótese propõe que as populações de Bos indicus devem ter surgido mais tardiamente por meio de cruzamentos e seleção a partir de bovinos Bos taurus (Epstein, 1971; Epstein e Mason, 1984; Payne, 1991). 


\subsection{O Nelore}

Como descrito por Santos (1998), a denominação Zebu veio da Índia juntamente com o gado importado no final do século XIX, e significa terra ou berço sagrado, enfatizando assim, o papel religioso dos bovinos. Para a ciência, a história do Zebu inicia-se no vale do Indo por volta de 3000 A.C.

Nos anos de 1500 A.C., em virtude da invasão dos arianos, a Índia desenvolveu uma civilização baseada no sistema de castas e para evitar conflitos com os vizinhos da região, cada marajá adotava um gado diferente. Por milhares de anos, esses gados foram se agrupando e formando as mais de 50 raças hoje existentes.

Segundo apresentado por Viacava et al. (2000) a expansão do zebu brasileiro pode ser dividida em quatro fases distintas. A primeira, caracterizada pelos cruzamentos desordenados com as raças nativas nos anos de 1890 a 1920, em que surgem os primeiros animais azebuados. Nos anos seguintes, de 1925 a 1945 ocorreu a fase em que a importação do gado indiano era proibida; com isso iniciaram os cruzamentos de zebuínos entre si, que culminou com o nascimento de raças como a Indubrasil, que rapidamente declinou devido à alta endogamia.

Os anos de 1945 a 1965 são caracterizados pela "pureza racial" e a partir desta época os princípios de melhoramento genético começam a ser aplicados, uma vez que a seleção fenotípica não era mais eficiente. $O$ último período, iniciado em 1965, se caracteriza pela utilização do Melhoramento Genético para características como carne e leite, tendência que permanece até os dias atuais.

A raça Nelore, formada a partir do gado Ongole, raça que apresenta uma mistura de pelo menos 14 outras, e também pelos zebus de Misore, representa a grande maioria dos bovinos nacionais na região acima dos trópicos, isso se deve à fertilidade, rusticidade e adaptação ao ambiente permitindo um sistema de produção extensivo (Santiago, 1960).

A entrada do Nelore no Brasil ocorreu em 1868, com a chegada de um casal de animais a bordo de um navio que ancorou em Salvador, Bahia. 
E por volta de 1870 aconteceram as primeiras importações de animais com a finalidade de criação (Santiago, 1972; Viacava et al., 2000).

Atualmente, esta raça tem sido melhorada geneticamente sendo exclusivamente destinada para produção de carne, embora na sua origem tenha sido utilizada para exploração leiteira (Santiago, 1987).

\subsection{DNA Mitocondrial}

Estudos evolutivos, principalmente relacionados ao esclarecimento da origem dos bovinos domésticos têm sido apoiados na análise do DNA mitocondrial (Loftus et al., 1994a e b; Bradley et al., 1996; Meirelles et al., 1999).

A mitocôndria, organela presente no citoplasma das células eucariotas e cuja principal função é a fosforilação oxidativa, é portadora de seu próprio genoma, composto por inúmeras cópias de DNA circular.

O DNA mitocondrial (mtDNA), localizado na membrana interna da organela, possui aproximadamente 16.500 nucleotídeos nos mamíferos, sendo que nos bovinos apresenta 16.338 (Anderson et al., 1982; Alberts et al., 1994; Lewin, 2001). Esta molécula codifica 13 enzimas participantes da fosforilação oxidativa, 22 tRNAs e 2 rRNAs (Anderson et al., 1981).

Comparando-se as seqüências de DNA em diversos organismos, pode-se notar que a taxa de mutação no curso da evolução é de 5 a 10 vezes maior no genoma mitocondrial que no genoma nuclear (Brown et al., 1979; Alberts et al., 1994), provavelmente devido a erros na replicação e baixa taxa de reparo do DNA mitocondrial.

Sabe-se que o DNA mitocondrial é herdado exclusivamente pela linha materna. No entanto, o exato mecanismo capaz de explicar este fato não foi ainda elucidado (Cummins, 1998; Chinnery e Turnbull, 2000). Estudos moleculares relatam que as mitocôndrias presentes nos espermatozóides são degradadas após a penetração no oócito, ou durante as primeiras clivagens embrionárias (Hiraoka e Hirao, 1998), confirmando a teoria de que 
o mtDNA materno predomina nos mamíferos (Giles et al., 1980; Shitara et al., 1998).

Polimorfismos na seqüência do mtDNA, entre raças $B$. taurus e $B$. indicus, foram também verificados em regiões menos variáveis como tRNAs e a origem da replicação da cadeia leve (Pegoraro et al., 1995).

Loftus et al. (1994a), com base no genoma mitocondrial bovino, sugerem que a domesticação dos animais Bos indicus tenha ocorrido independentemente dos Bos taurus a partir de um ancestral comum há pelo menos 200.000 anos (Correns, 1909; Hutchinson et al., 1974; Giles et al., 1980).

\subsection{Marcadores nucleares}

Nos últimos anos, com os avanços nas tecnologias de análise do genoma, vários métodos de detecção de polimorfismos no DNA, tais como marcadores microssatélites e satélites, têm sido utilizados em diversas espécies com diferentes propósitos (Miesfeld et al., 1981; Hamada et al., 1982; Jeffreys et al., 1985; Georges et al., 1988; Weber e May, 1989; Litt e Luty, 1989; Tautz, 1989; Fries et al., 1990; Steffen et al., 1993; Guérin et al., 1994; Kemp et al., 1995; Zhang et al., 1995).

\subsubsection{DNA Microssatélite}

Os DNAs microssatélites são pequenas seqüências não codificadoras de 1 a 6 pares de base, com número variável de repetições em tandem e que representam a principal fração do DNA (Fries et al., 1993). Os microssatélites apresentam alto grau de polimorfismo, podendo ser facilmente detectados por meio da técnica de Reação em Cadeia da Polimerase (PCR) (Mullis, 1990) e visualizados após eletroforese em gel de poliacrilamida.

Atualmente, os microssatélites, são os marcadores moleculares que mais contribuem para a elaboração de mapas de ligação na espécie bovina 
(Bishop et al., 1994; Kappes et al., 1997), estudos de estrutura de populações (Estoup, et al., 1995) e reconstrução de relações filogenéticas entre populações (Machugh et al., 1997). Mesmo assim, são poucos os estudos que têm analisado a estrutura, a distribuição e o tipo de polimorfismo apresentado pelos loci microssatélites.

Em relação à estrutura, eles podem ser agrupados em três tipos principais, de acordo com o número de nucleotídeos repetidos. Os dinucleotídeos representam a grande maioria dos microssatélites utilizados, e sua densidade varia amplamente entre as espécies animais e vegetais. As unidades repetidas mais comuns no reino animal para este tipo são CA. Os trinucleotídeos também são comuns em plantas e animais, mas o tamanho e o polimorfismo destas repetições são semelhantes aos dinucleotídeos. Para os tetranucleotídeos, um grande número de repetições GATA/GACA pode ocorrer em organismos superiores e mesmo apresentando um alto grau de polimorfismo, eles são raramente usados em estudos de populações (Jarne e Lagoda, 1996).

Estudos in vitro propõem que a "replication slippage" pode ser uma das principais origens do polimorfismo observado entre populações (Schlötterer e Tautz, 1992). Neste processo, o número de repetições dos nucleotídeos pode aumentar ou diminuir quando a célula replica seu DNA antes da divisão (Moxon e Wills, 1999).

Não se sabe ao certo se estas seqüências apresentam alguma função específica, mas acredita-se que desempenhem um papel na compactação e descompactação do DNA durante a evolução dos genomas eucariotos (Brutlag, 1980; Doolittle e Sapienza, 1980). Seu padrão de mutação é extremamente alto, sendo 10.000 vezes mais aptas a ganhar ou perder uma repetição de uma geração para outra do que um gene qualquer (Moxon e Willis, 1999).

Como as relações filogenéticas entre os gêneros da tribo Bovini são ainda muito contraditórias (Groves, 1981; Nowak, 1991; Wall et al., 1992), vários estudos utilizando microssatélites têm sido publicados recentemente. Ritz et al. (2000), no intuito de determinar a confiabilidade das relações 
filogenéticas publicadas até 0 presente momento, testaram 20 loci microssatélites que revelaram uma grande divergência entre as espécies analisadas. Com base nestes resultados, os autores apresentam os tempos de divergência estimados para $B$. taurus e $B$. indicus, aproximadamente 0,31 a 0,82 milhões de anos e sugerem uma reorganização no gênero Bos.

Machugh et al. (1997) investigando as relações evolutivas e geográficas entre bovinos Africanos, Europeus e Asiáticos, utilizaram 20 microssatélites e verificaram diferenças na distribuição dos alelos para metade dos loci testados. Isso permitiu a separação entre animais zebuínos e taurinos, fato que fortalece a hipótese de origem distinta para estas subespécies.

Segundo apresentado por Bradley et al. (1998), a Figura 1, desenvolvida a partir das distâncias genéticas entre diferentes populações bovinas, sugere uma origem híbrida de zebuínos africanos. Estes animais não mostram distinção entre Bos indicus e Bos taurus, quando analisados em função da diversidade mitocondrial, mas a freqüência de alelos microssatélites reforçam a evidência de hibridização.

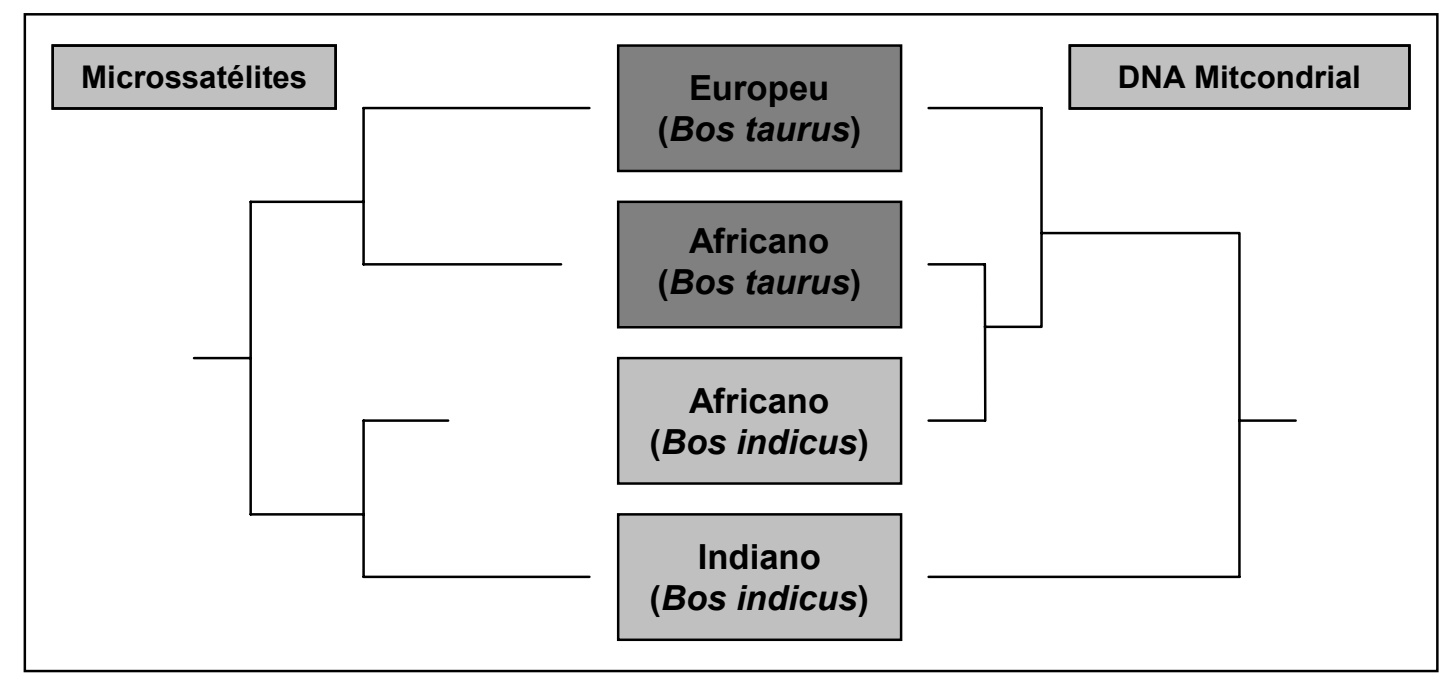

FIGURA 1 - Reconstrução filogenética com base em marcadores microssatélites e DNA mitocondrial (adaptado de Bradley et al., 1998). 
Em recentes estudos dos bovinos do oeste da África, Hall e Bradley (1995) apontam que as raças taurinas, resistentes à tripanossomíase, estão ameaçadas por cruzamento com raças zebuínas que são susceptíveis. Estes dois grupos de bovinos mostram uma distribuição de alelos característica em aproximadamente metade dos marcadores testados, especialmente para o locus ETH225, em que os zebuínos mostram uma freqüência mais alta de alelos de maior peso molecular que os taurinos, o que permite estimar a mistura genética em populações supostamente híbridas.

Almeida et al. (2000) visando estimar a variabilidade de quatro microssatélites em um rebanho bovino híbrido (Nelore e Aberdeen Angus), verificaram que, entre os três microssatélites testados de maior polimorfismo, o marcador TGLA122 apresentou dois alelos ainda não descritos, sugerindo a participação de genes zebuínos na população estudada. De acordo com os autores, apesar do alto polimorfismo e dos altos níveis de diversidade intrapopulacional apresentados por este microssatélite, ele é eficiente na construção de filogenia de bovinos.

Moazami-Goudarzi et al. (1997) estudando 17 loci microssatélites e 13 marcadores bioquímicos em 10 raças de bovinos, concluíram que a quantidade de microssatélites utilizada não foi suficiente, embora na literatura alguns autores sugiram que de 5 a 12 microssatélites seja um número suficiente para detectar diferenças entre espécies não intimamente relacionadas (Machugh et al., 1997).

\subsubsection{DNA Satélite}

Outra classe de seqüências repetitivas é composta pelos DNAs Satélites (stDNA), seqüências complexas de DNA que podem variar de 2 a algumas centenas de pares de bases arranjadas em tandem (Alberts et al., 1994).

Estas seqüências, geralmente localizadas na heterocromatina dos cromossomos, estão associadas com as regiões próximas aos centrômeros, 
telômeros ou no cromossomo $Y$ (Charlesworth et al., 1994). A fração do genoma composta por DNA satélite é muito variável, de 0 a $66 \%$ tanto entre as espécies quanto entre as famílias evolutivamente aparentadas (Beridze, 1986).

Os primeiros estudos a respeito dos DNAs satélites tiveram início em meados dos anos de 1960. Os cientistas, observando o padrão de reassociação da dupla fita de DNA de organismos superiores, verificaram que algumas seqüências de nucleotídeos eram freqüentemente repetidas. Esta suposição foi confirmada pela observação de que $10 \%$ do DNA de camundongos se reassocia rapidamente (Waring e Britten, 1966).

O stDNA recebe este nome por que os primeiros DNAs desse tipo que foram descobertos tinham uma proporção incomum de nucleotídeos, o que tornou possível separá-los do restante do DNA celular, como um componente menor, ou satélite, por ultracentrifugação em gradiente de densidade de Cloreto de Césio (CsCl) (Alberts et al., 1994).

Estes DNAs podem ser isolados pela técnica de RFLP ("Restriction Fragment Length Polimorphysm"), em que os fragmentos são obtidos por meio de endonucleases de restrição (Kelly e Smith, 1970). Quando um stDNA é digerido por uma endonuclease que reconhece o sítio de restrição da unidade de repetição os fragmentos obtidos são quase ou completamente idênticos em virtude das clivagem em sítios regularmente espaçados (Lewin, 2001).

O genoma bovino contém pelo menos oito tipos de DNA satélite, dois dos quais tem a densidade de $1711 \mathrm{~g} / \mathrm{cm}^{3}$ quando centrifugados em $\mathrm{CsCl}$, sendo então denominados de satélites 1711a e 1711b (Macaya et al., 1978).

O satélite 1711a representa $1,7 \%$ do DNA total e tem uma unidade de repetição de 1413 pares de bases já seqüenciadas. O satélite 1711b representa 7,1\% do genoma bovino (Macaya et al., 1978), e parte das unidades repetidas deste satélite podem ser descritas como uma inserção de unidades repetidas provenientes do satélite $1715\left(1715 \mathrm{~g} / \mathrm{cm}^{3} \mathrm{em} \mathrm{CsCl}\right)$ (Taparowsky e Gerbi, 1982), ou também conhecido como Satélite I, isolados do timo de bezerros (Płucienniczack et al., 1982). Experimentos de 
mapeamento, hibridização demonstraram que parte da seqüência inserida no satélite $1711 \mathrm{~b}$ é homóloga ao satélite 1711a, e o restante da seqüência tem origem desconhecida (Streeck, 1981).

Kopecka et al. (1978) verificaram que alguns componentes do DNA, ricos em nucleotídeos $\mathrm{G}$ e $\mathrm{C}$, apresentam o mesmo comportamento e a mesma densidade em diferentes gradientes, fato que impulsionou a busca por outros métodos de detecção, tais como a análise de fragmentos de restrição por eletroforese. Este método confirmou a diferença entre os dois satélites $1711 \mathrm{~g} / \mathrm{cm}^{3}$ sendo que o satélite $1711 \mathrm{a}$, quando digerido com HaellI, apresentou bandas de alto peso molecular comparadas com o 1711b.

Outra descoberta é a existência de tamanhos repetidos em vários componentes satélites como 1711a, 1711b e 1715 que compartilham seqüências comuns. A presença de comprimentos idênticos nas repetições sugere uma origem comum dos satélites (Kopecka et al., 1978).

O satélite bovino $1720 \mathrm{~b}\left(1720 \mathrm{~g} / \mathrm{cm}^{3}\right.$ em $\left.\mathrm{CsCl}\right)$ constitui aproximadamente $0,1 \%$ do genoma bovino e sua organização simples de 46 pb é composta de duas seqüências relacionadas de 23 pb, ambas complementares (Pöschl e Streeck, 1980). Já o satélite 1706, apresenta 2350 pb cujas unidades repetidas podem ser divididas em 4 segmentos de 23 pb semelhantes às seqüências do satélite 1720b (Pech et al., 1979), o que sugere a origem a partir de um ancestral comum.

Embora existam muitos trabalhos envolvendo a estrutura, localização e a variabilidade dos DNA's satélites, várias hipóteses que foram formuladas a respeito da função do DNA satélite, não foram definitivamente demonstradas até o presente momento.

Chalesworth et al. (1986) propuseram que a distribuição dos satélites nos cromossomos não era em virtude da natureza das seqüências, mas sim em decorrência de um equilíbrio evolutivo entre a deriva genética, a seleção natural e pressão de mutação.

Willard (1998) e Koch (2000) propõem que o DNA $\alpha$-satélite humano desempenhe algum papel no funcionamento dos centrômeros. Csink e Henikoff (1998) acreditam que os DNAs satélites são necessários para a 
manutenção de regiões de replicação tardia, conseqüentemente garantindo que o centrômero é a última região a se replicar no cromossomo.

Choo (2000) sugere que seqüências específicas de DNA não são necessárias para a formação dos centrômeros, atribuindo este fato à mecanismos epigenéticos. Um dos aspectos que salientam esta afirmação é que DNAs satélites em organismos que vão de insetos, plantas e fungos a mamíferos e outros vertebrados não apresentam uma conservação das seqüências de nucleotídeos, sugerindo que uma seqüência universal dos centrômeros não existe, ou ao menos é contraditório aos conhecimentos atuais.

Analisando os DNA satélites III e 1711b de taurinos (Bos taurus), zebuínos (Bos indicus) e seus híbridos, Nijman et al. (1999) verificaram que espécies intimamente aparentadas podem possuir seqüências variáveis destes satélites, o que pode ser utilizado como marcador para estudar a introgressão de genes de zebuínos em animais Bos taurus.

Nijman e Lenstra (2001) comparando regiões satélites de algumas espécies de Bos e Bison, verificaram que existe uma ampla variação em alguns dos principais satélites estudados, e que o padrão de restrição gerado pela digestão dos fragmentos sugere que possa ter ocorrido recombinação das seqüências variáveis. 


\section{MATERIAL E MÉTODOS}

\subsection{Local do experimento}

O experimento foi desenvolvido no Laboratório de Morfo-fisiologia Molecular e Desenvolvimento no Departamento de Ciências Básicas da Faculdade de Zootecnia e Engenharia de Alimentos da Universidade de São Paulo - Campus de Pirassununga.

\subsection{Animais}

A raça Nelore, como mencionada anteriormente, é a mais comum na América do Sul e desempenha um importante papel na economia brasileira sendo, portanto, escolhida para o desenvolvimento deste trabalho. Desta forma, 104 animais Nelore PO e POI de diversos rebanhos e com pedigrees registrados foram selecionados.

\subsection{Extração do DNA}

Para a realização dos estudos, $5 \mathrm{ml}$ de sangue periférico foram coletados em tubos a vácuo, contendo $54 \mu \mathrm{l}$ de EDTA $0,5 \mathrm{M}$ e mantidos sob refrigeração até serem processados. A extração do DNA foi realizada a partir de $1 \mathrm{ml}$ sangue como descrito por Sambrook e Russel (2001). Resumidamente, as hemácias foram lisadas com uma solução de Lise de Hemácias (12mMTris- $\mathrm{HCl} \mathrm{pH} 8.2 ; 0,32 \mathrm{M}$ Sacarose; 5mM EDTA e 1\% de Triton 100X) e os glóbulos brancos peletizados digeridos com proteinase $\mathrm{K}$ 
por 3 horas. As proteínas foram então precipitadas com solução de $\mathrm{NaCl} 5 \mathrm{M}$ e o sobrenadante transferido para outro tubo. O DNA total foi precipitado com adição de 3 volumes de etanol absoluto, desidratado e rediluído em $50 \mu \mathrm{l}$ de $\mathrm{H}_{2} \mathrm{O}$ ultrafiltrada.

\subsection{DNA Mitocondrial (mtDNA)}

A amplificação do mtDNA foi realizada utilizando-se os primers BosmtF1 5 '-cccaacgaggaaaatatacc-3' e BosmtR1 5'-aaccgcaaacaacctcttcc3', sintetizados para amplificar uma região do gene ND5 do genoma mitocondrial dos nucleotídeos 11770 ao 12525 de acordo com Anderson et al. (1982) (Figura 2). Para a reação de PCR utilizou-se 100 ng de DNA para uma reação de $50 \mu \mathrm{l}$, em condições de tampão determinadas pelo fabricante, $200 \mu \mathrm{M}$ de dATP, dTTP, dCTP, dGTP, 1,25U de Taq DNA polimerase e $0,2 \mu \mathrm{M}$ de cada oligonucleotídeo iniciador (primer) em 35 ciclos de 30 segundos à $94^{\circ} \mathrm{C}, 45$ segundos à $58^{\circ} \mathrm{C}$ e 45 segundos à $72^{\circ} \mathrm{C}$. $\mathrm{O}$ mtDNA amplificado foi então digerido com a enzima de restrição Hind III, corado com Brometo de etídeo e submetido a eletroforese em gel de agarose $1,5 \%$ em TBE $1 \mathrm{X}$.

O mtDNA foi analisado e, de acordo com a presença ou ausência do sítio de restrição da enzima Hind III, os indivíduos foram classificados como portadores de mtDNA de $B$. taurus ou portadores de mtDNA $B$. indicus. 


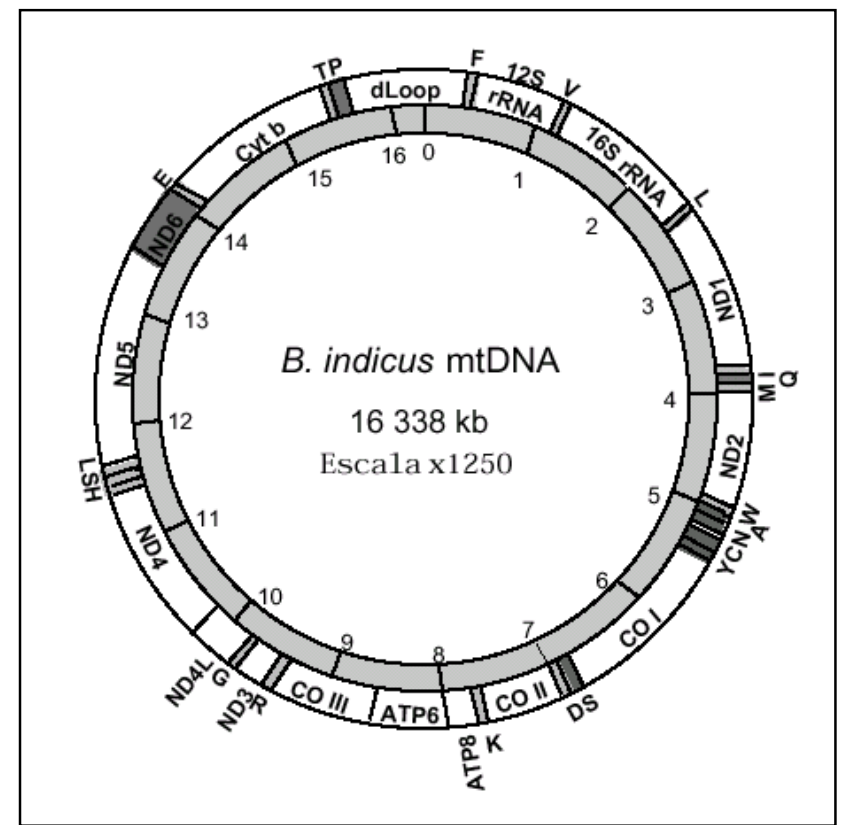

FIGURA 2 - Esquema do DNA mitocondrial de Bos indicus.

\subsection{Amplificação dos microssatélites}

Cinco regiões do DNA que produzem fragmentos polimórficos de microssatélite HEL1, HEL9, ETH225, ILSTS005 e INRA063 (Tabela 1; Figura 3) foram amplificadas. Para a realização da PCR foram utilizados 100ng de DNA para uma reação de $50 \mu \mathrm{l}$, em condições de tampão determinadas pelo fabricante, $200 \mu \mathrm{M}$ de dATP, dTTP, dCTP, dGTP, 1,25U de Taq DNA polimerase e 0,2 $\mu \mathrm{M}$ de cada oligonucleotídeos iniciador (primers) sendo que os primers reversos foram marcados com fluorescência (FAM, Fluoresceína ou Hex). A PCR foi realizada em 35 ciclos de desnaturação, anelamento e extensão, sendo que para cada microssatélite a temperatura de anelamento foi ajustada conforme Tabelas 2 e 3.

Alíquotas dos fragmentos amplificados foram misturadas a solução de formamida, desnaturadas à $95^{\circ} \mathrm{C}$ e submetidas à eletroforese em gel de poliacrilamida $6 \%$, a uma potência de $1500 \mathrm{~V}$ por 40 minutos. Os fragmentos 
foram visualizados após excitação com laser utilizando o scaner laser Fuji FLA 3000G e analisados com o auxílio do software Science Lab - Image Gauge versão 3.12. A Figura 4 ilustra a localização dos microssatélites amplificados nos respectivos cromossomos.

TABELA 1 - Seqüência dos oligonucleotídeos iniciadores para amplificação dos microssatélites e sua localização cromossômica (cr).

\begin{tabular}{|c|c|c|c|c|}
\hline Marcador & cr & & Primer (5'-3') & Referência \\
\hline \multirow[b]{2}{*}{ HEL9 } & & $\mathbf{F}$ & CCCATTCAGTCTTCAGAGGT & Kaukinen e \\
\hline & 8 & $\mathbf{R}$ & Fluoro-CACATCCATGTTCTCАСCAC & Varvio (1993) \\
\hline \multirow[b]{2}{*}{ ETH225 } & & $\mathbf{F}$ & GATCACCTTGCCACTATTTCCT & Steffen et al. \\
\hline & 9 & $\mathbf{R}$ & Fam-ACATGACAGCCAGCTGCTACT & (1993) \\
\hline \multirow{3}{*}{ ILSTS005 } & & $\mathbf{F}$ & GGAAGCAATGAAATCTATAGCC & Brezinsky et al \\
\hline & 10 & $\mathbf{R}$ & Tet-TGTTCTGTGAGTTTGTAAGC & (1993) \\
\hline & & $\mathbf{F}$ & CAACAGCTATTTAACAAGGA & Kaukinen e \\
\hline \multirow[t]{2}{*}{ HEL1 } & 15 & $\mathbf{R}$ & Fluoro-AGGCTACAGTCCATGGGATT & Varvio (1993) \\
\hline & & $\mathbf{F}$ & ATTTGCACAAGCTAAATCTAACC & Vaiman et al. \\
\hline INRA063 & 18 & $\mathbf{R}$ & Tet-AAACCACAGAAATGCTTGGAAG & (1994) \\
\hline
\end{tabular}




\section{ETH225 (149 pb)}

gat cac ctt gcc act att tcc $t$ ccaacatatgtgtgtgcgtgcacacacacacacac acacacacacacacacacacatgatagccactcctttctctaatgccacagaattacacag tcaactctct agt agc agc tgg ctg tca tgt

HEL1 (110 pb)

agg cta cag tcc atg gga tt gaaagagttggacacgacagaagcaacttagcgca cacacacacac acacacacacacacacacaccaag tcc ttg tta aat agc tgt tg

HEL9 (169 pb)

ccc att cag tct tca gag gt gtgtgcagagtgtgtgtgtgtgtgtgtgtgtgtgtgt gtgtgtgtgtgtgtgtgtgttggcacatgcatgcatttgttaagtcgtgtgctgtagtgtgctccaagg ccaggtgccctgtgcccogtg gtg gtg aga aca tgg atg tg

ILSTS005 (aprox. 186 pb)

ggaagcaatgaaatctatagcc (seqüência não disponível e número de repetições de aproximadamente 90 nucleotídeos)

tgttctgtgagtttgtaagc

INRA063 ( $177 \mathrm{pb})$

atttgcacaagctaaatctaaccaagttccccacaaagtaacggcataaatgtacagggaa gtgaaacacacacacacacacacacacacacatatatacaaaataatcctatccctgagttctt cctaacttttatagtactttccaaactttcttccaagcatttctgtggttt

FIGURA 3 - Seqüência de nucleotídeos dos fragmentos microssatélites amplificados (Oligonucleotídeos iniciadores em itálico). 


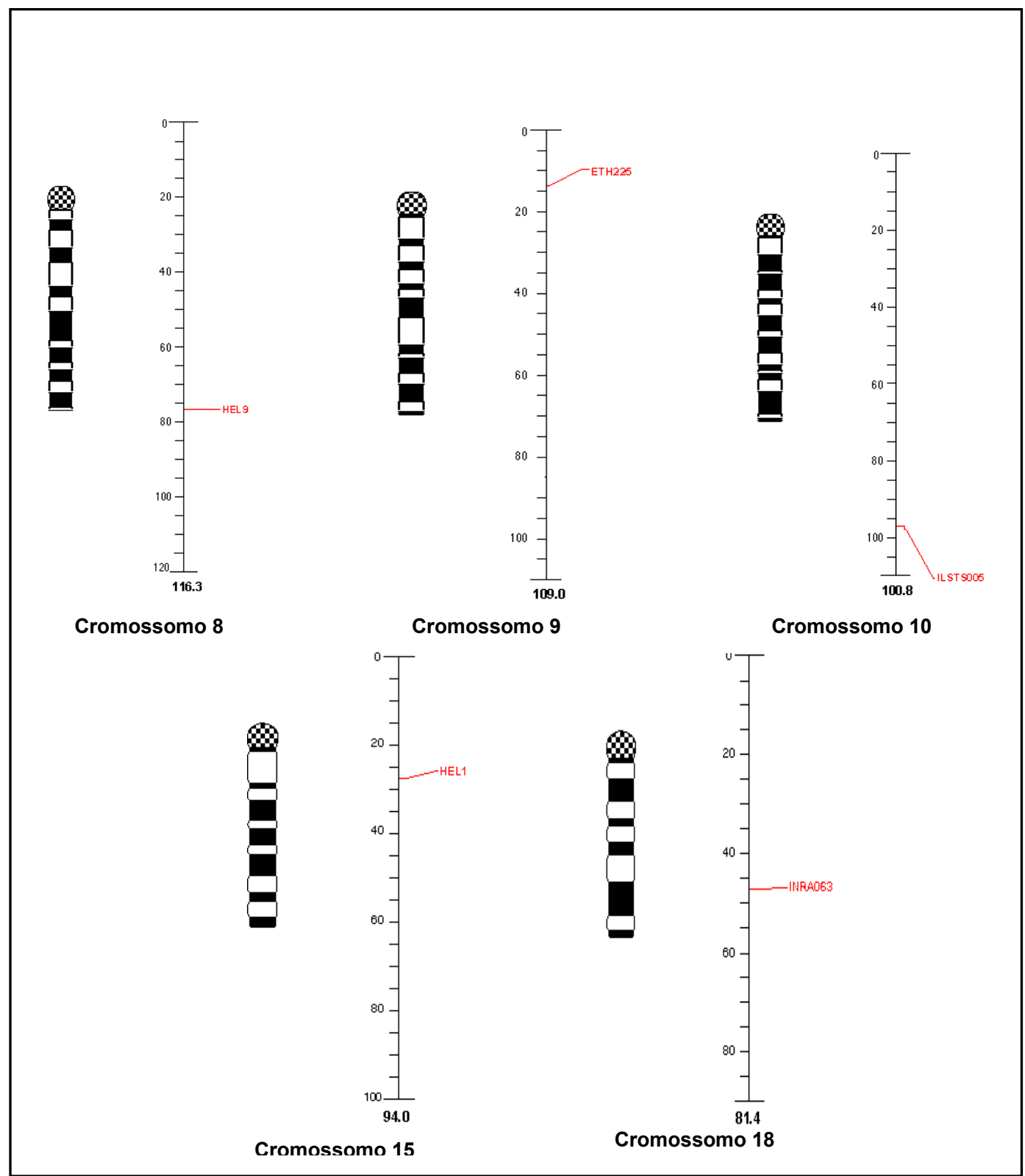

FIGURA 4 - Esquema dos cromossomos determinando a localização dos microssatélites utilizados. 
TABELA 2 - Programa utilizado na amplificação dos Microssatélites.

\begin{tabular}{cccc}
\hline Etapa & Temperatura & Tempo & $\mathbf{N}^{\circ}$ ciclos \\
\hline Pré-desnaturação & $94^{\circ} \mathrm{C}$ & 4 minutos & 1 \\
Desnaturação & $94^{\circ} \mathrm{C}$ & 30 segundos & \\
Anelamento & $\mathrm{X}^{\circ} \mathrm{C}$ & 45 segundos & 35 \\
Extensão & $72^{\circ} \mathrm{C}$ & 45 segundos & \\
Extensão final & $72^{\circ} \mathrm{C}$ & 10 minutos & 1 \\
Resfriamento & $4^{\circ} \mathrm{C}$ & indeterminado & \\
\hline
\end{tabular}

Onde: $\mathrm{X}=$ Temperatura de anelamento dos primers.

TABELA 3 - Temperaturas de anelamento dos primers utilizadas na amplificação dos fragmentos microssatélites.

\begin{tabular}{cc}
$\begin{array}{c}\text { Locus } \\
\text { Microssatélite }\end{array}$ & $\begin{array}{c}\text { Temperatura de } \\
\text { Anelamento }\left({ }^{\circ} \mathrm{C}\right)\end{array}$ \\
\hline HEL9 & $58 / 56$ \\
ETH225 & 58 \\
ILSTS005 & $50 / 48$ \\
HEL1 & $58 / 56$ \\
INRA063 & $50 / 48$ \\
\hline
\end{tabular}




\subsection{PCR RFLP do satélite 1711b}

No intuito de medir a freqüência relativa de seqüências $B$. taurus em um animal isoladamente, amplificou-se parte da região satélite do DNA denominada $1711 \mathrm{~b}$, localizada na região centromérica.

As condições da PCR estão descritas na Tabela 4 e a seqüência do fragmento de $875 \mathrm{pb}$ amplificado pelos primers 1711b F2 $5^{\prime}$-ccc act acc tct ctc tga aaa-3' e 1711b R1 5'-tga tcc agg gta ttc gaa gga-3' está demonstrada na Figura 5. O resultado da amplificação foi digerido à $37^{\circ} \mathrm{C}$ por 3 horas com as enzimas de restrição Sau 3A (Mbo I) e Msp I (ou Hpa II), que cliva parte dos satélites de origem $B$. indicus (Tabela 5).

Após a digestão dos produtos de amplificação, os fragmentos do DNA satélite foram corados com Brometo de Etídeo $(0,5 \mu \mathrm{g} / \mathrm{ml})$ e separados em gel de agarose 2\%. O DNA foi visualizado após excitação com laser utilizando o scaner laser Fuji FLA 3000G.

TABELA 4 - Programa utilizado na amplificação do Satélite 1711b.

\begin{tabular}{cccc}
\hline Etapa & Temperatura & Tempo & $\mathbf{N}^{\circ}$ de ciclos \\
\hline Pré-desnaturação & $94^{\circ} \mathrm{C}$ & 4 minutos & 1 \\
Desnaturação & $94^{\circ} \mathrm{C}$ & 15 segundos & \\
Anelamento & $62^{\circ} \mathrm{C}$ & 45 segundos & 35 \\
Extensão & $72^{\circ} \mathrm{C}$ & 45 segundos & \\
Extensão final & $72^{\circ} \mathrm{C}$ & 10 minutos & 1 \\
Resfriamento & $4^{\circ} \mathrm{C}$ & Indeterminado & 1 \\
\hline
\end{tabular}


5'-ccc act acc tct ctc tga aaa aag agt ta....(480 pb)........tgt taa cag gcc

tcc ggg cca gaa gat $g .$. (290 pb) ttt cct gat ctt cgC

(Msp I)

cta cgc cgt ctc tcc ttc gaa tac cct gga tca- 3'

(Sau3A I)

FIGURA 5 - Fragmento de 875 pb amplificado do DNA satélite 1711b de Bos taurus (oligonucleotídeos iniciadores em negrito e itálico e o sítio de restrição sublinhado).

TABELA 5 - Possíveis fragmentos após digestão do DNA satélite 1711b.

\begin{tabular}{|c|c|c|c|c|c|c|}
\hline Enzimas & mtDNA & \multicolumn{4}{|c|}{ Fragmentos (pb) } & Total (pb) \\
\hline \multirow{2}{*}{$\begin{array}{c}\text { Msp I } \\
\text { (Hpa II) }\end{array}$} & \multirow{2}{*}{ B. indicus } & \multicolumn{2}{|c|}{754} & \multicolumn{2}{|c|}{121} & 875 \\
\hline & & 402 & 352 & \multicolumn{2}{|c|}{121} & 875 \\
\hline \multirow{2}{*}{$\begin{array}{l}\text { Sau 3A } \\
\text { (Mbo I) }\end{array}$} & B. indicus & 701 & 132 & 37 & 5 & 875 \\
\hline & B. taurus & \multicolumn{2}{|c|}{833} & 37 & 5 & 875 \\
\hline
\end{tabular}

\subsection{Seqüenciamento do DNA satélite $1711 \mathrm{~b}$}

Os produtos de PCR de seis amostras (dois animais Holandeses, dois Nelore mtDNA indicus e dois Nelore mtDNA taurus) contendo a região de interesse do DNA satélite 1711b foram extraídos do gel do agarose 1,5\% com o kit Qiaex $\|^{\circledR}$ (Qiagen, Germany), purificados pelo kit GFX PCR DNA (Amershan Biosciences) e seqüenciados com o dideoxi terminador BigDye ${ }^{\mathrm{TM}}$ (Applied Biosystems, US) no seqüenciador ABI Prism 377 DNA (Applied Biosystems, US). 


\subsection{Análises estatísticas}

Como os marcadores utilizados, DNA microssatélite e satélite, são codominantes, as freqüências genotípicas foram calculadas por contagem simples dos alelos após eletroforese e as estimativas de diversidade gênica e heterozigosidade foram obtidas por meio do programa Microsatellite Tools for Excel. As freqüências foram utilizadas para estimar a contribuição do Bos taurus nos rebanhos analisados.

Para o cálculo dos parâmetros populacionais utilizou-se o programa RSTCALC 2.2 (Goodman, 1997). O RHO é um estimador não viesado do RST de Slatkin (1995) e esta medida representa a proporção da variação entre populações. As estimativas são feitas para locus individuais e para o conjunto de loci analisados, calculado entre as populações e pares de populações. Este procedimento também determina se os valores de RHO entre os loci são significativamente diferentes de zero por testes de permutação.

A distância genética $(\delta \mu)^{2}$, medida utilizada para estimar a divergência entre duas populações, foi obtida segundo métodos estabelecidos por Goldstein, et al. (1995), que elimina a dependência do tamanho da população, supondo que esta está em equilíbrio, e diminui a variância.

O Equilíbrio de Hardy-Weinberg foi calculado por cada locus em cada população utilizando-se o programa GENEPOP versão 3.3.

As freqüências dos padrões de restrição do DNA Satélite foram comparadas pelo teste de análise de variância e a comparação das médias foi realizada pelo método de $\mathrm{T}$ de Student, segundo os procedimentos do programa JMP 2.2 (SAS Institute Inc. Cary, Carolina do Norte, EUA). 


\section{RESULTADOS E DISCUSSÃO}

\subsection{DNA mitocondrial e Microssatélites}

Estudos do DNA mitocondrial indicam uma divergência de raças taurinas e zebuínas a partir de um ancestral comum de aproximadamente 210.000 anos, bem antes dos eventos de domesticação dos bovinos (Loftus et al., 1994). Em função do longo tempo de divergência entre essas raças, a hipótese formulada para este trabalho foi que marcadores satélites e microssatélites possam informar a participação taurina em uma população de animais Nelore. Esta hipótese também se baseia na sugestão de que alguns autores usam os microssatélites por serem sensíveis na diferenciação de populações muito próximas (Ritz et al., 2000).

Para tanto, foram analisados 104 animais da raça Nelore que foram agrupados de acordo com sua origem mitocondrial em mtDNA taurus e mtDNA indicus, além de 8 animais das raças Holandesa, Ayrshire, Limousin, Charolesa, Aberdeen Angus e Piemontesa, cedidos pelo Instituto Roslin, Escócia, e que serviram como padrões para a genotipagem dos loci microssatélites ETH225, HEL1, HEL9, INRA063 e ILSTS005 propostos para o estudo.

Entre os animais analisados da raça Nelore, ou seja, animais oriundos de rebanhos $\mathrm{PO}$ e $\mathrm{POI}$, apenas $37,5 \%$ apresentaram DNA mitocondrial de zebu, avaliados pela ausência do sítio de restrição para a enzima Hind III no gene ND5, como mostra a Figura 6. 


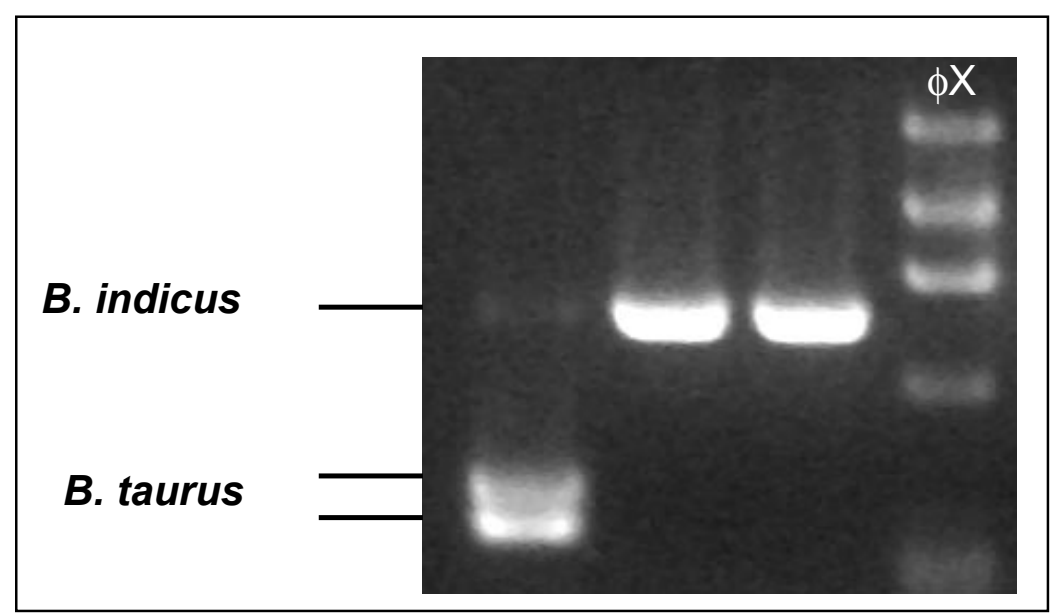

FIGURA 6 - Resultado da digestão com enzima de restrição Hind III na análise do DNA mitocondrial de bovinos da raça Nelore. Animais com mtDNA Bos indicus (i) e Animais com mtDNA Bos taurus (t).

Nas análises referentes aos microssatélites, considerando-se os animais portadores de mtDNA de zebuínos e taurinos, foram encontrados 23 alelos para os 5 loci microssatélites, o que representa uma média de $4,6 \pm 1,82$ alelos por locus. O número de alelos por locus variou de 2 (INRA063) a 7 (ETH225). A freqüência dos alelos estimada para cada locus está apresentada na Tabela 6, e a distribuição dos alelos está ilustrada nas Figuras 7, 8, 9, 10 e 11. 
TABELA 6 - Freqüência dos alelos dos cinco loci microssatélites estudados na raça Nelore, para animais mtDNA indicus e taurus.

\begin{tabular}{|c|c|c|c|c|c|c|c|c|c|c|c|c|c|c|}
\hline \multicolumn{3}{|c|}{$\begin{array}{l}\text { ETH225 } \\
(n=208)\end{array}$} & \multicolumn{3}{|c|}{$\begin{array}{c}\text { HEL1 } \\
(n=184)\end{array}$} & \multicolumn{3}{|c|}{$\begin{array}{c}\text { HEL9 } \\
(n=184)\end{array}$} & \multicolumn{3}{|c|}{$\begin{array}{l}\text { ILSTS005 } \\
(n=198)\end{array}$} & \multicolumn{3}{|c|}{$\begin{array}{c}\text { INRA063 } \\
(n=184)\end{array}$} \\
\hline Alelo & $\begin{array}{l}\text { mtDNA } \\
\text { indicus }\end{array}$ & $\begin{array}{c}\text { mtDNA } \\
\text { taurus }\end{array}$ & Alelo & $\begin{array}{l}\text { mtDNA } \\
\text { indicus }\end{array}$ & $\begin{array}{c}\text { mtDNA } \\
\text { taurus }\end{array}$ & Alelo & $\begin{array}{l}\text { mtDNA } \\
\text { indicus }\end{array}$ & $\begin{array}{l}\text { mtDNA } \\
\text { taurus }\end{array}$ & Alelo & $\begin{array}{l}\text { mtDNA } \\
\text { indicus }\end{array}$ & $\begin{array}{c}\text { mtDNA } \\
\text { taurus }\end{array}$ & Alelo & $\begin{array}{l}\text { mtDNA } \\
\text { indicus }\end{array}$ & $\begin{array}{l}\text { mtDNA } \\
\text { taurus }\end{array}$ \\
\hline 139 & 0,01 & 0,02 & 103 & 0,12 & 0,09 & 151 & 0,23 & 0,20 & 182 & 0,06 & 0,08 & 175 & 0,45 & 0,46 \\
\hline 143 & 0,19 & 0,22 & 105 & 0,35 & 0,38 & 153 & 0,27 & 0,30 & 184 & 0,28 & 0,23 & 177 & 0,55 & 0,54 \\
\hline 147 & 0,13 & 0,08 & 107 & 0,15 & 0,16 & 157 & 0,23 & 0,20 & 186 & 0,28 & 0,54 & & & \\
\hline 149 & 0,06 & 0,06 & 111 & 0,24 & 0,22 & 159 & 0,26 & 0,29 & 190 & 0,37 & 0,15 & & & \\
\hline 151 & 0,01 & 0,02 & 113 & 0,15 & 0,14 & 165 & 0,02 & 0,01 & & & & & & \\
\hline 159 & 0,33 & 0,31 & & & & & & & & & & & & \\
\hline 161 & 0,26 & 0,28 & & & & & & & & & & & & \\
\hline Total & 1,00 & 1,00 & & 1,00 & 1,00 & & 1,00 & 1,00 & & 1,00 & 1,00 & & 1,00 & 1,00 \\
\hline
\end{tabular}




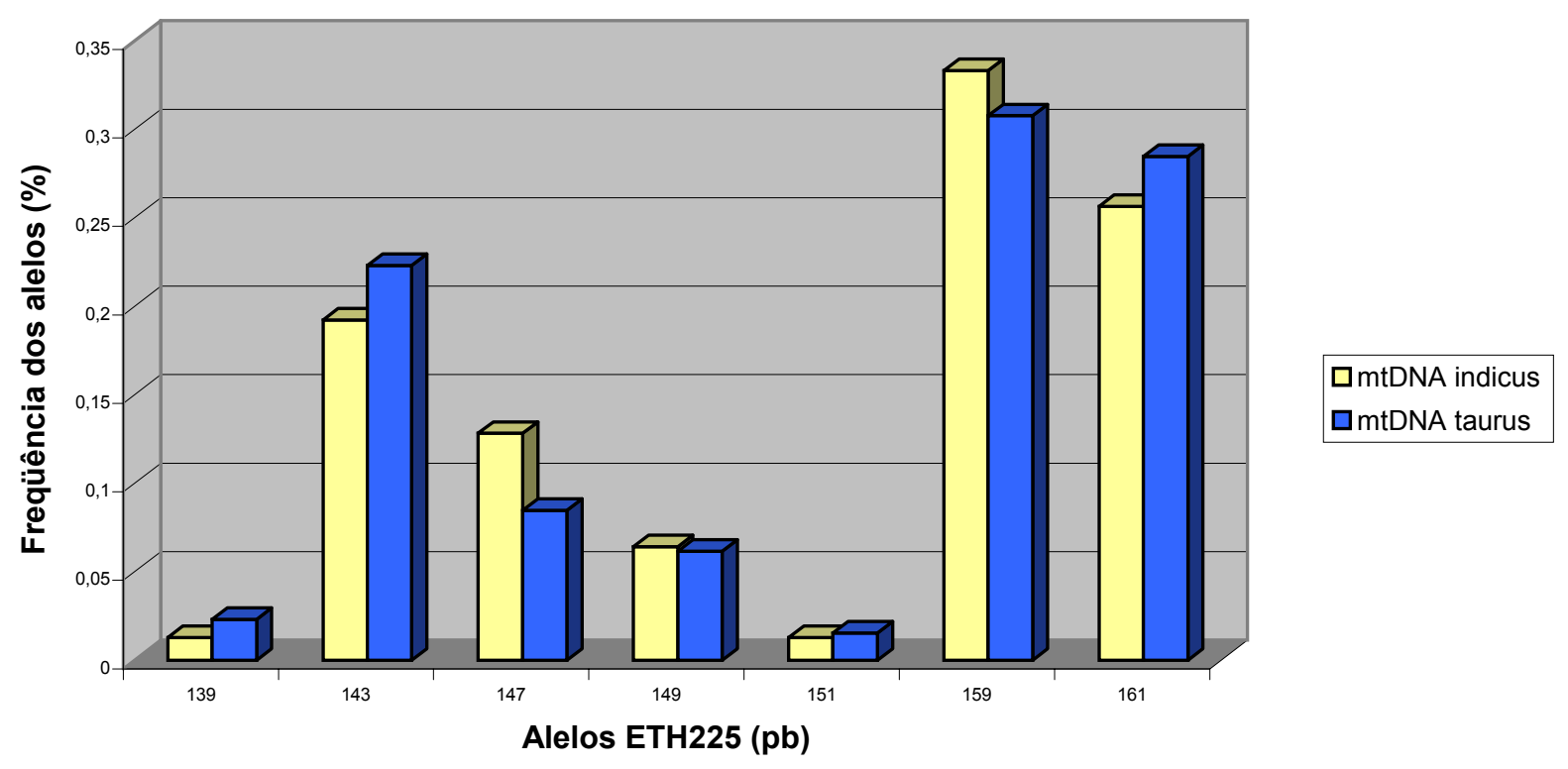

FIGURA 7 - Freqüência dos alelos amplificados do microssatélite ETH225, em animais da raça Nelore classificados com base no mtDNA em Bos taurus e Bos indicus.

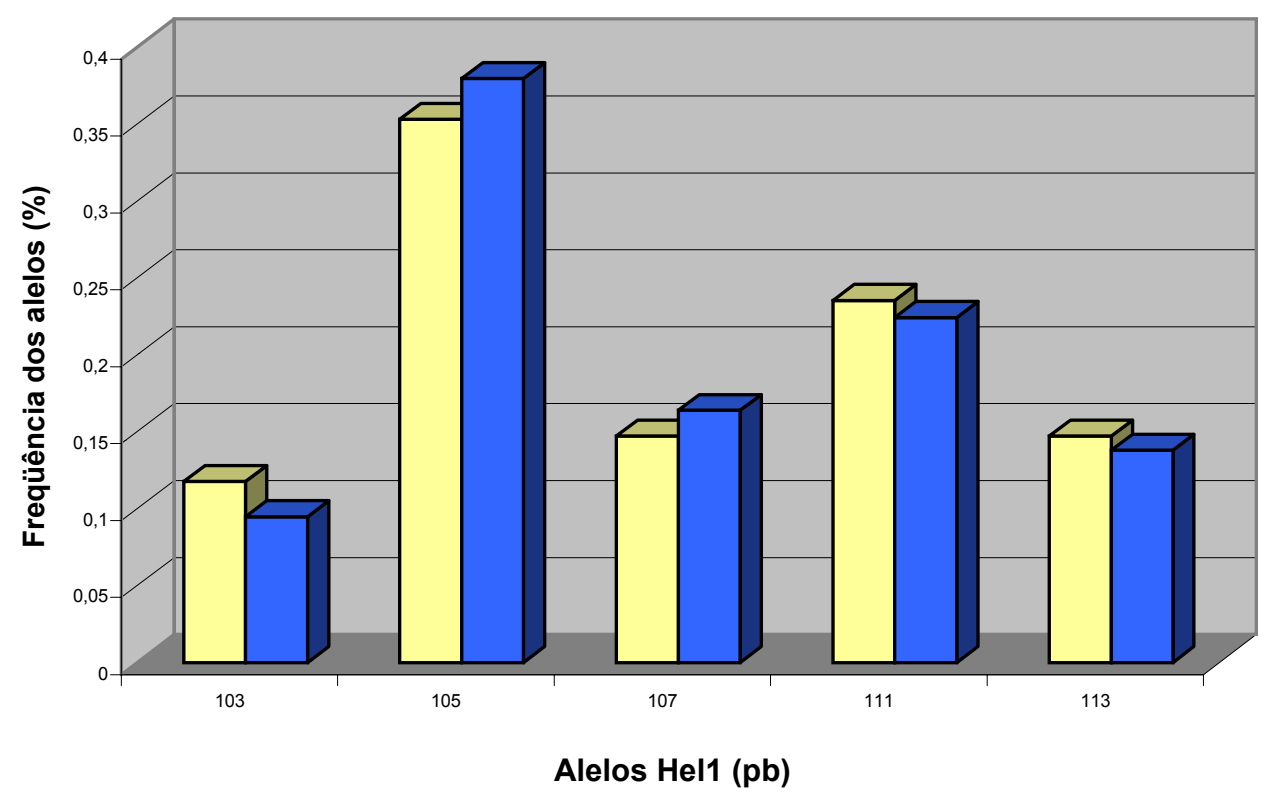

$\square \mathrm{mtDNA}$ indicus $\square \mathrm{mtDNA}$ taurus

FIGURA 8 - Freqüência dos alelos amplificados do microssatélite HEL1, em animais da raça Nelore classificados com base no mtDNA em Bos taurus e Bos indicus. 


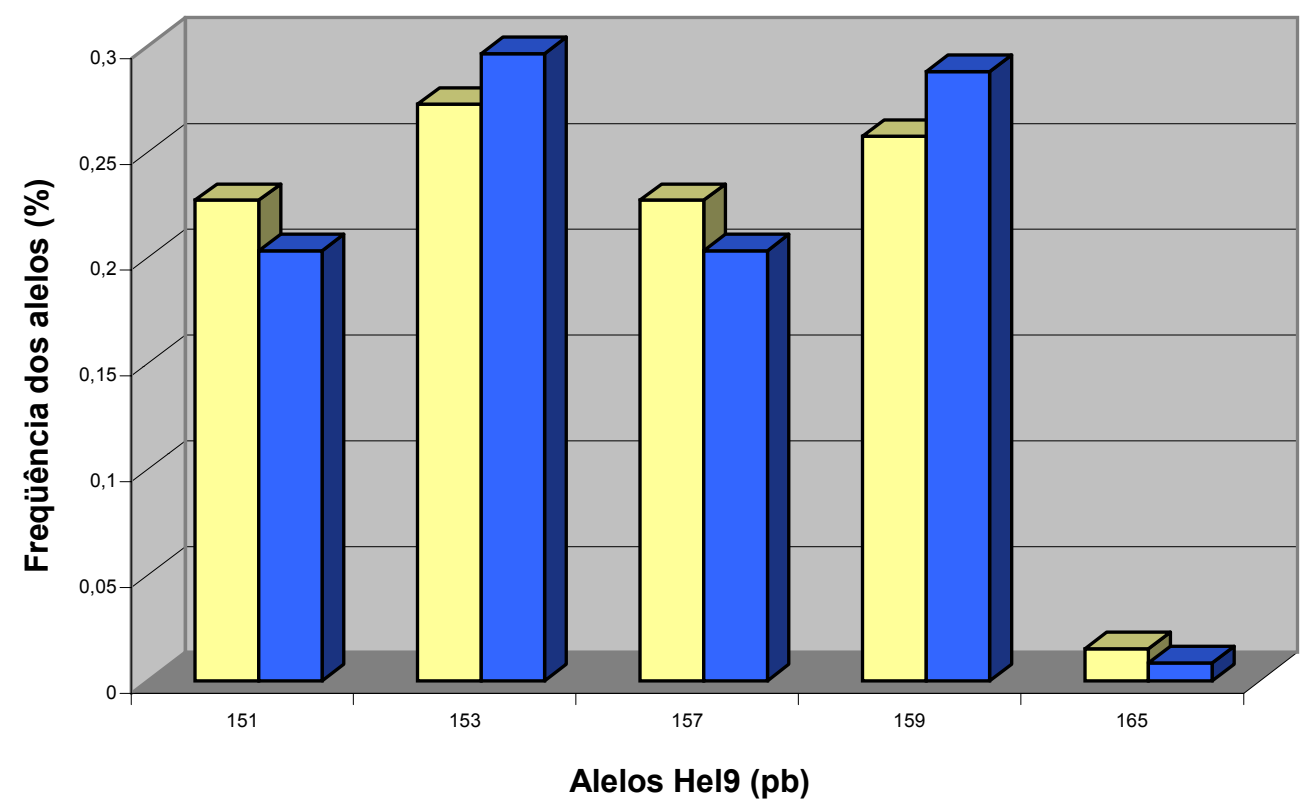

$\square m$ tDNA indicus $\square m t D N A$ taurus

FIGURA 9 - Freqüência dos alelos amplificados do microssatélite HEL9, em animais da raça Nelore classificados com base no mtDNA em Bos taurus e Bos indicus.

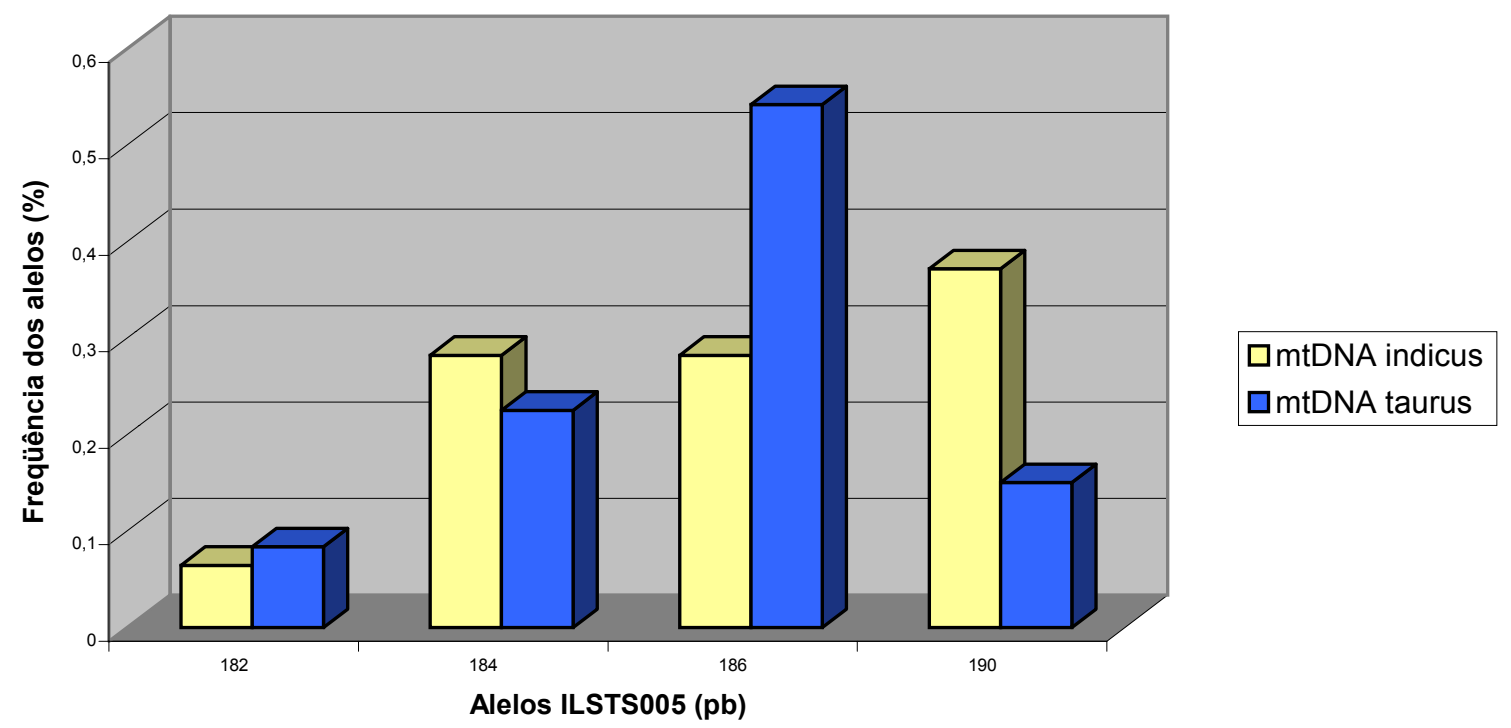

FIGURA 10 - Freqüência dos alelos amplificados do microssatélite ILSTS005, em animais da raça Nelore classificados com base no mtDNA em Bos taurus e Bos indicus. 


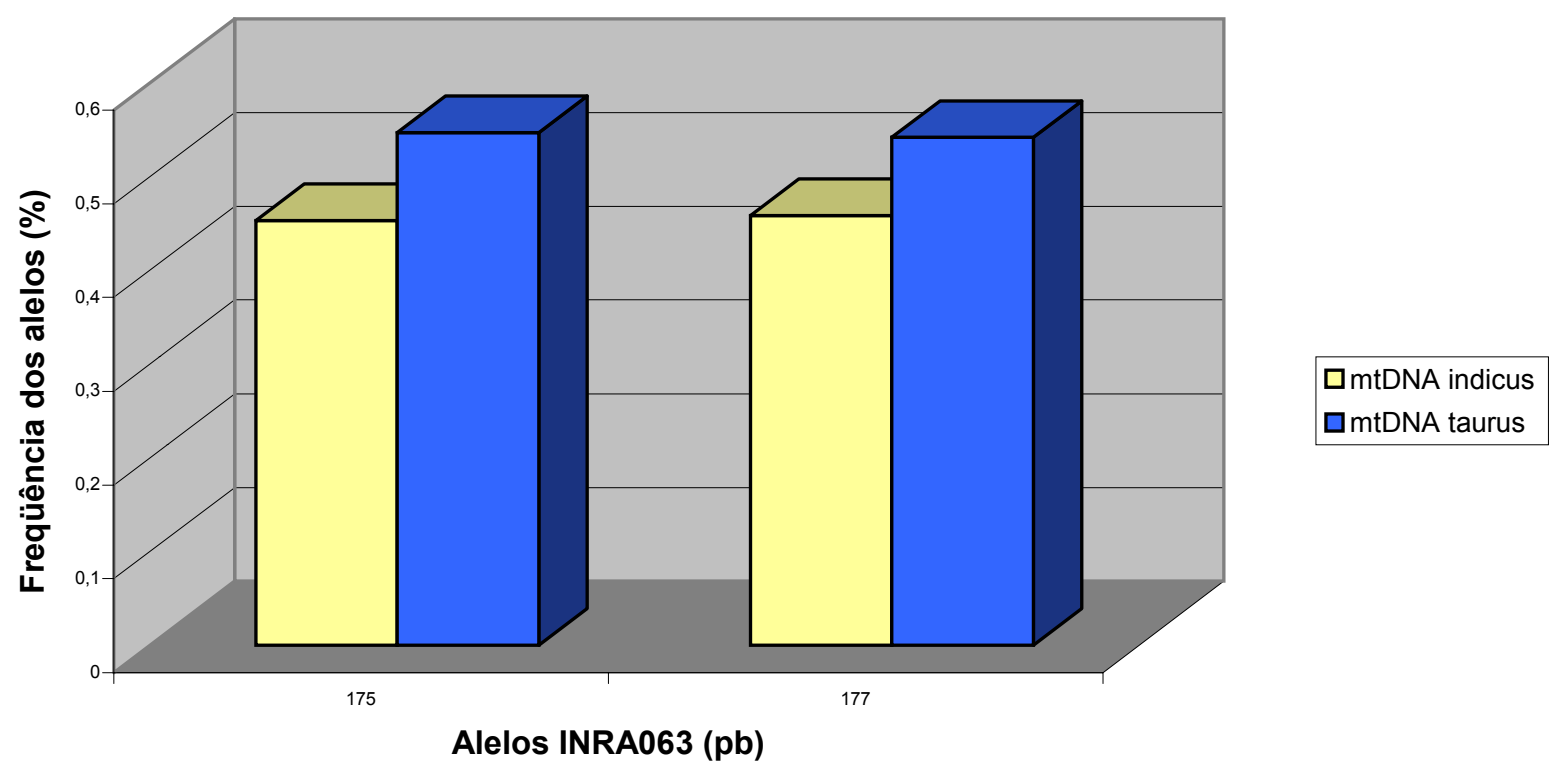

FIGURA 11 - Freqüência dos alelos amplificados do microssatélite IINRA063, em animais da raça Nelore classificados com base no mtDNA em Bos taurus e Bos indicus.

Alguns autores relatam a existência de loci específicos para raças zebuínas africanas e indianas quando comparadas com raças taurinas européias, como é o caso dos microssatélites ETH225, ILSTS005 e HEL1, entre outros (MacHugh et al., 1997; Hanotte et al., 1997).

Nos resultados obtidos, embora não sejam evidenciadas diferenças significativas entre a freqüência dos alelos de animais da raça Nelore mtDNA taurus e mtDNA indicus, observa-se que alguns alelos são mais comumente encontrados em animais de uma ou outra origem mitocondrial. Para o microssatélite ETH225, por exemplo, os alelos 147 e 159 são mais comuns em animais Nelore mtDNA indicus ao passo que os alelos 143 e 161 são mais comuns em animais que possuem mtDNA taurus.

Hall e Bradley (1995), ao comparar a freqüência dos alelos taurinos e zebuínos para o microssatélite ETH225, verificaram alta freqüência do alelo 158 específicos para animais zebus enquanto alelos de baixo peso molecular são mais evidentes em animais taurinos, fato que não foi claramente evidenciado entre os animais Nelore analisados neste trabalho a 
não ser pela alta freqüência de alelos 159 e 161 para os animais das duas origens mitocondriais. $O$ mesmo pode ser evidenciado para os microssatélites HEL1, HEL9, em que pequenas diferenças, embora não significativas, foram encontradas para os dois grupos analisados entre os animais da raça Nelore.

A ausência de diferenças significativas entre as duas populações de Nelore analisadas pode ser explicada pela pequena amostragem e pelo número de microssatélites utilizados, uma vez que as duas populações são muito próximas. Moazami-Goudarzi et al. (1997) sugerem um maior número de animais e de marcadores para detectar diferenças intra-raciais significativas.

Moazami-Goudarzi et al. (1997), também citam que alguns parâmetros devem ser observados na utilização de microssatélites para estudos populacionais, entre eles, a presença de alelos nulos, característica deste tipo de marcador, que pode resultar em um falso resultado de homozigose. A alta freqüência dos alelos 184, 186 e 190 em homozigose verificada no microssatélite ILSTS005 pode ser gerada pela presença de alelos nulos. Para confirmar esta hipótese seria necessário checar as progênies dos animais analisados além de descartar a possibilidade de que alguns destes alelos não estejam sendo amplificados (Martín-Burriel et al., 1999). Tambasco et al. (2000) citam a provável ocorrência de alelos nulos para o microssatélite BM1224 em uma amostra de animais Nelore visto que aproximadamente metade das mães homozigotas não transmitiu seu alelo para seus filhos.

A heterozigosidade e diversidade gênica de $\mathrm{Nei}(\mathrm{Nei}, 1987)$ para os microssatélites nas populações analisadas, incluindo os animais europeus cedidos pelo Instituto Roslin estão apresentados nas Tabelas 7 e 8. 
TABELA 7 - Valores médios da diversidade gênica e Heterozigosidade para as três populações analisadas; animais de origem européia e da raça Nelore mtDNA taurus e indicus.

\begin{tabular}{ccccc}
\hline População & $\mathrm{N}$ & $\mathrm{N}^{0}$ de Loci & Diversidade gênica & Heterozigosidade \\
\hline Europeus & 8 & 5 & $0,54 \pm 0,08$ & $0,47 \pm 0,07$ \\
mtDNAindicus & 39 & 5 & $0,70 \pm 0,05$ & $0,65 \pm 0,03$ \\
mtDNAtaurus & 65 & 5 & $0,68 \pm 0,05$ & $0,69 \pm 0,02$ \\
Total & 104 & 5 & $0,69 \pm 0,05$ & $0,67 \pm 0,02$ \\
\hline
\end{tabular}

TABELA 8 - Diversidade gênica e Heterozigosidade para cada microssatélite nas três populações analisadas, animais de origem européia e da raça Nelore mtDNA taurus e indicus.

\begin{tabular}{ccccc}
\hline Locus & População & $\mathrm{N}^{\circ}$ de alelos & Diversidade gênica & Heterozigosidade \\
\hline \multirow{2}{*}{ ETH225 } & Europeus & 6 & 0,808 & 0,875 \\
& mtDNAindicus & 7 & 0,775 & 0,846 \\
& mtDNAtaurus & 7 & 0,768 & 0,800 \\
\hline \multirow{2}{*}{ HEL1 } & Europeus & 4 & 0,650 & 0,500 \\
& mtDNAindicus & 5 & 0,774 & 0,941 \\
& mtDNAtaurus & 5 & 0,757 & 0,913 \\
\hline \multirow{2}{*}{ HEL9 } & Europeus & 4 & 0,516 & 0,375 \\
& mtDNAindicus & 5 & 0,767 & 1,000 \\
& mtDNAtaurus & 5 & 0,752 & 1,000 \\
\hline \multirow{2}{*}{ ILSTS005 } & Europeus & 2 & 0,400 & 0,250 \\
& mtDNAindicus & 4 & 0,707 & 0,205 \\
& mtDNAtaurus & 4 & 0,631 & 0,366 \\
\hline \multirow{2}{*}{ INRA063 } & Europeus & 2 & 0,325 & 0,375 \\
& mtDNAindicus & 2 & 0,503 & 0,281 \\
& mtDNAtaurus & 2 & 0,500 & 0,383 \\
\hline
\end{tabular}


No total, 29 haplótipos foram encontrados para os cinco microssatélites. A Figura 12 mostra algum dos haplótipos encontrados para o microssatélite ETH225 na eletroforese em gel de poliacrilamida desnaturante 6\%. Para a determinação dos haplótipos também se considerou o gráfico da intensidade de branco na área de migração dos fragmentos de DNA, gerada pelo software Image Gauge, que pode ser visualizada na Figura 13. Na Tabela 9 e nas Figuras 14, 15, 16, 17 e 18, estão os valores das freqüências dos haplótipos.

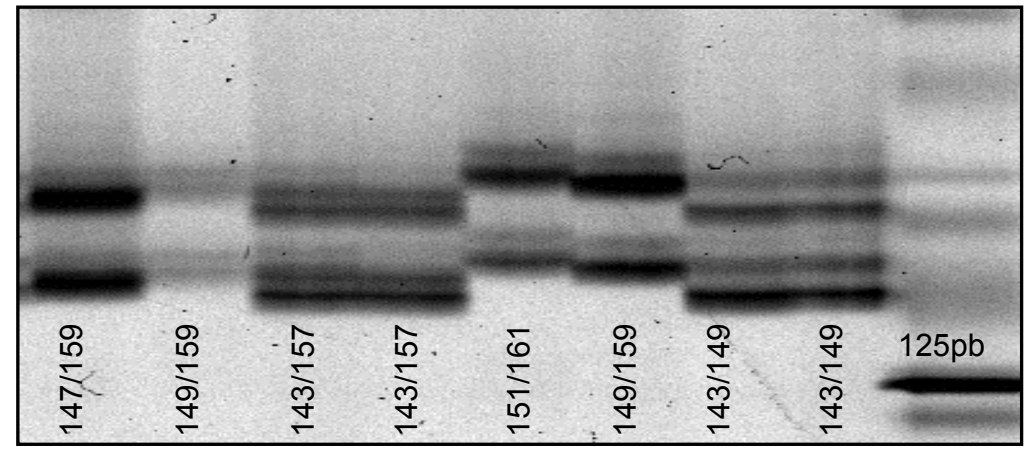

FIGURA 12 - Polimorfismo do microssatélite ETH225 em animais da raça Nelore. Gel de Poliacrilamida desnaturante 6\%, primers marcados com FAM. 

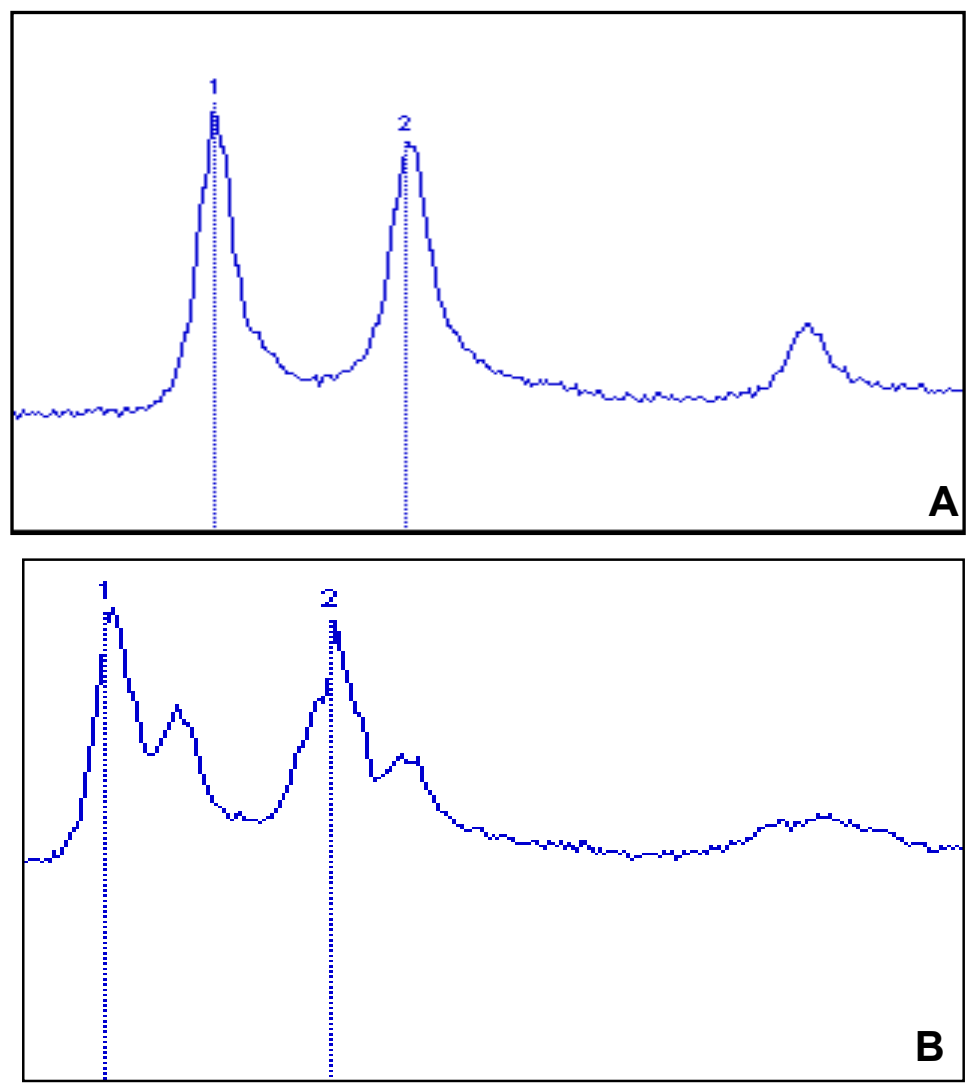

FIGURA 13 - Intensidade de branco na área de migração dos fragmentos de DNA do microssatélite HEL9. Na figura 13a está representado um animal de genótipo 153-159 e na figura 13b um animal de genótipo 151157. 
TABELA 9 - Freqüência dos haplótipos dos cinco microsatélites estudados na raça Nelore, para animais mtDNA indicus e taurus.

\begin{tabular}{|c|c|c|c|c|c|c|c|c|c|c|c|c|c|c|}
\hline \multicolumn{3}{|c|}{$\begin{array}{l}\text { ETH225 } \\
(n=104)\end{array}$} & \multicolumn{3}{|c|}{$\begin{array}{l}\text { HEL1 } \\
(n=92)\end{array}$} & \multicolumn{3}{|c|}{$\begin{array}{l}\text { HEL9 } \\
(n=92)\end{array}$} & \multicolumn{3}{|c|}{$\begin{array}{c}\text { ILSTS005 } \\
(\mathrm{n}=99)\end{array}$} & \multicolumn{3}{|c|}{$\begin{array}{c}\text { INRA063 } \\
(\mathrm{n}=92)\end{array}$} \\
\hline $\begin{array}{c}\text { Hapló- } \\
\text { tipos }\end{array}$ & $\begin{array}{l}\text { mtDNA } \\
\text { indicus }\end{array}$ & $\begin{array}{l}\text { mtDNA } \\
\text { taurus }\end{array}$ & $\begin{array}{c}\text { Hapló- } \\
\text { tipos }\end{array}$ & $\begin{array}{l}\text { mtDNA } \\
\text { indicus }\end{array}$ & $\begin{array}{l}\text { mtDNA } \\
\text { taurus }\end{array}$ & $\begin{array}{c}\text { Hapló- } \\
\text { tipos }\end{array}$ & $\begin{array}{l}\text { mtDNA } \\
\text { indicus }\end{array}$ & $\begin{array}{c}\text { mtDNA } \\
\text { taurus }\end{array}$ & $\begin{array}{c}\text { Hapló- } \\
\text { tipos }\end{array}$ & $\begin{array}{l}\text { mtDNA } \\
\text { indicus }\end{array}$ & $\begin{array}{l}\text { mtDNA } \\
\text { taurus }\end{array}$ & $\begin{array}{c}\text { Hapló- } \\
\text { tipos }\end{array}$ & $\begin{array}{l}\text { mtDNA } \\
\text { indicus }\end{array}$ & $\begin{array}{l}\text { mtDNA } \\
\text { taurus }\end{array}$ \\
\hline $139-149$ & 0,03 & 0,03 & 103-107 & 0,24 & 0,19 & $151-157$ & 0,45 & 0,41 & $182-184$ & 0,03 & 0,02 & $175-175$ & 0,31 & 0,27 \\
\hline $143-143$ & 0,15 & 0,20 & $105-105$ & 0,03 & 0,09 & $153-159$ & 0,52 & 0,58 & $182-186$ & 0,03 & 0,02 & $175-177$ & 0,28 & 0,38 \\
\hline $143-147$ & 0,08 & 0,03 & $105-111$ & 0,41 & 0,31 & $153-165$ & 0,03 & 0,02 & $182-190$ & 0,08 & 0,13 & $177-177$ & 0,41 & 0,35 \\
\hline $147-159$ & 0,13 & 0,06 & $107-111$ & 0,06 & 0,14 & & & & $184-186$ & 0,08 & 0,20 & & & \\
\hline $149-159$ & 0,05 & 0,02 & $113-113$ & 0,03 & & & & & $186-186$ & 0,23 & 0,43 & & & \\
\hline $151-161$ & 0,03 & 0,03 & & & & & & & $190-190$ & 0,33 & 0,08 & & & \\
\hline $159-161$ & 0,49 & 0,52 & & & & & & & & & & & & \\
\hline $139-161$ & 0,00 & 0,02 & & & & & & & & & & & & \\
\hline
\end{tabular}




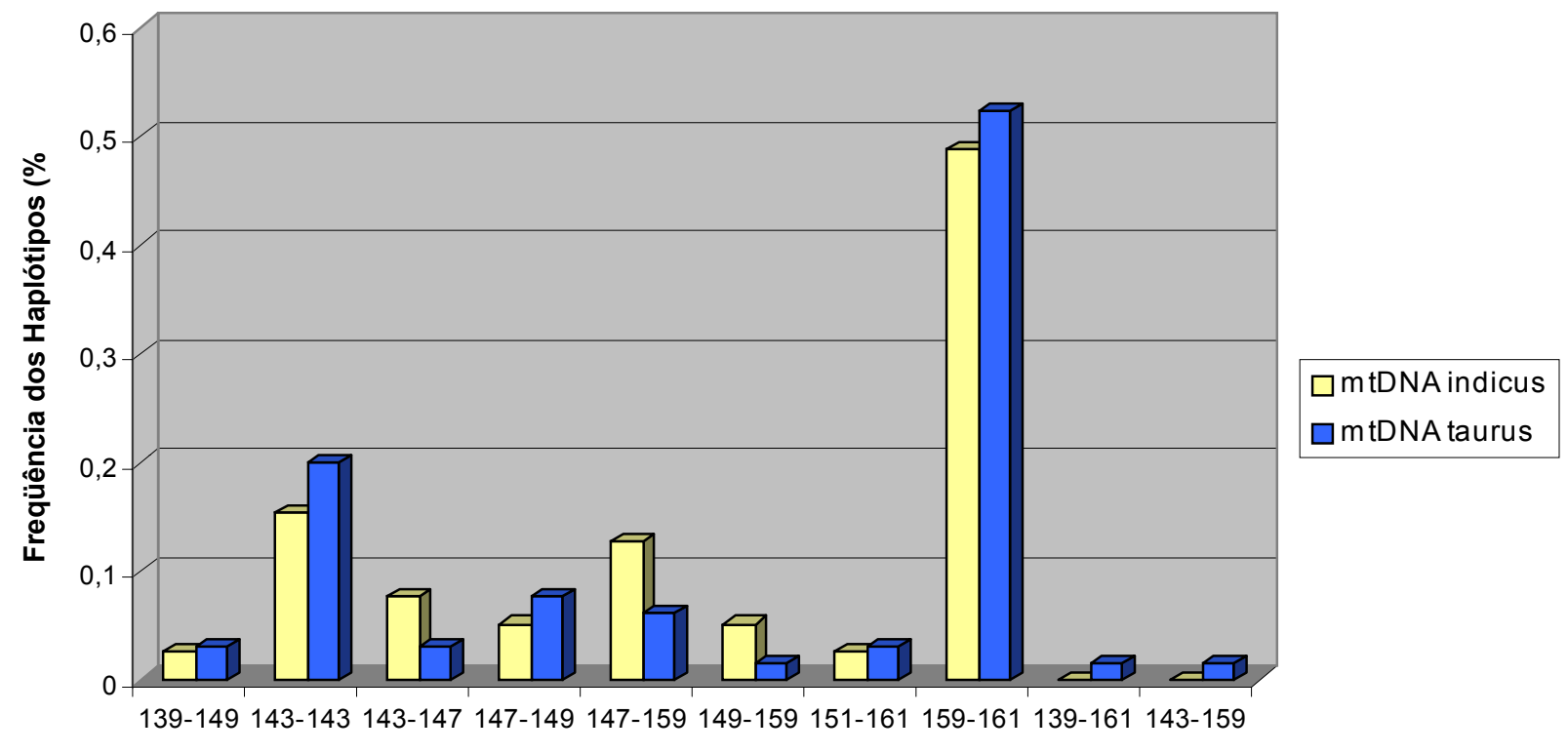

Haplótiplos ETH225

FIGURA 14 - Haplótipos para o locus microssatélite ETH225 encontrados na raça Nelore.

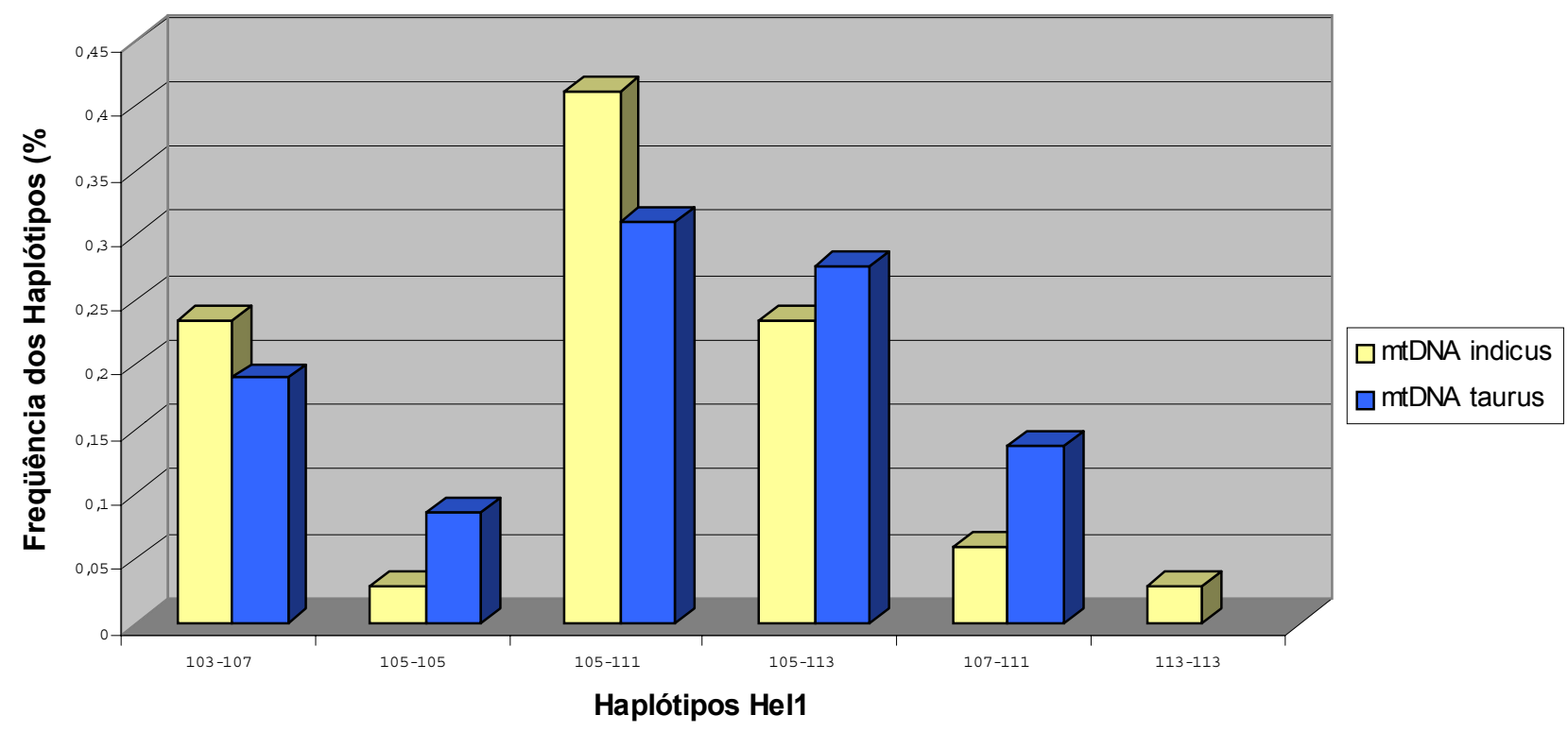

FIGURA 15 - Haplótipos para o locus microssatélite HEL1 encontrados na raça Nelore. 


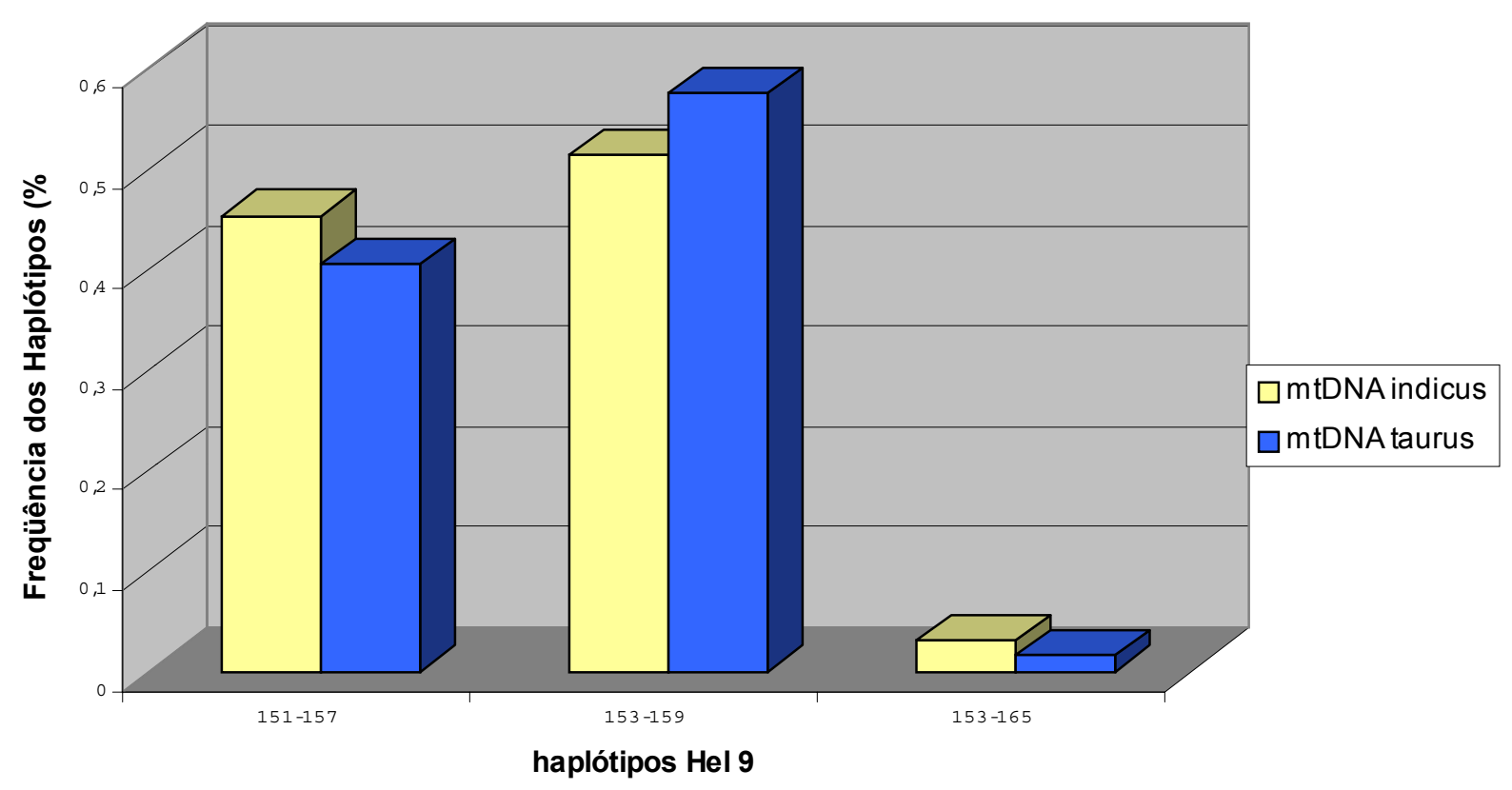

FIGURA 16 - Haplótipos para o locus microssatélite HEL9 encontrados na raça Nelore.

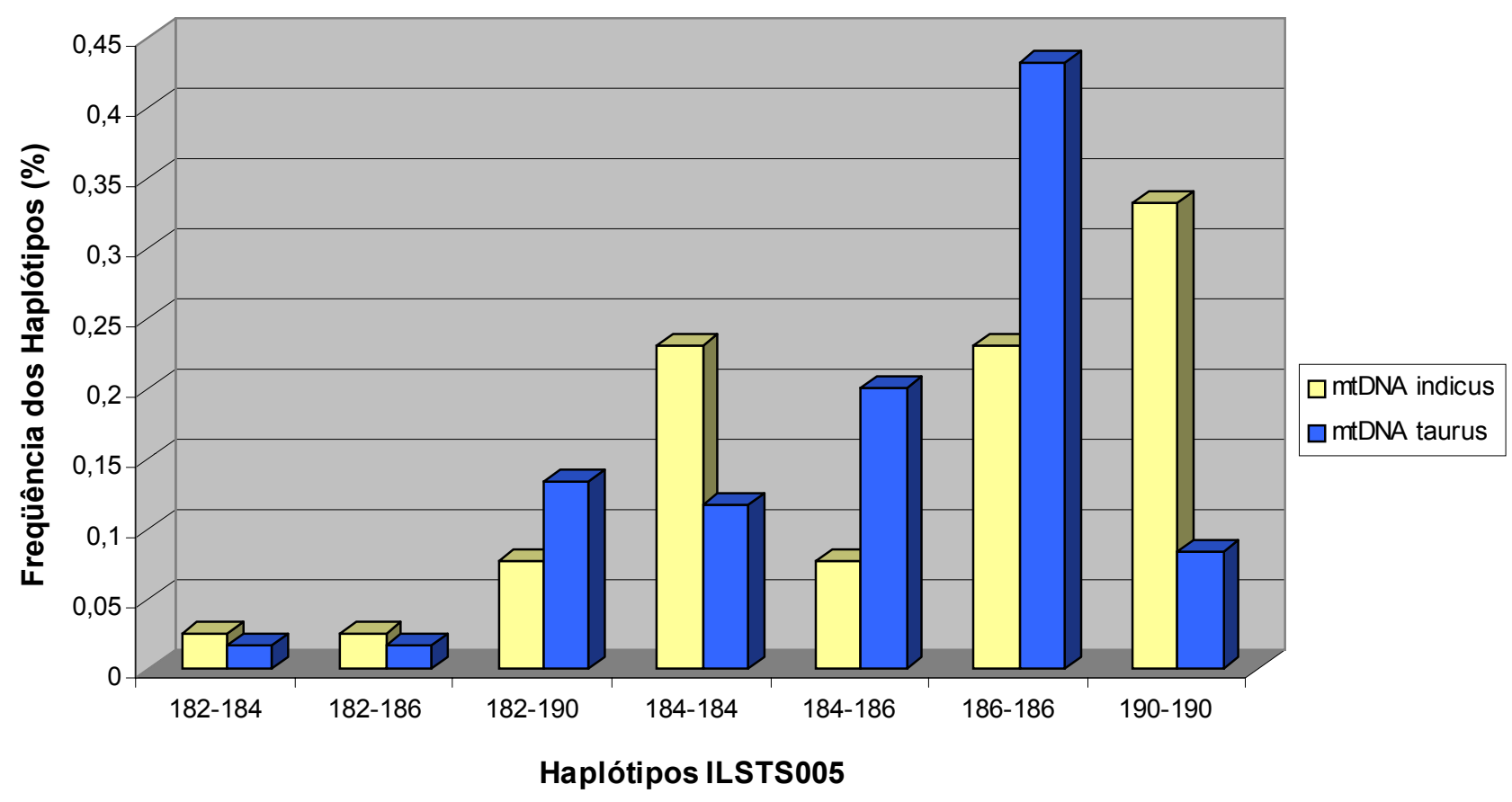

FIGURA 17 - Haplótipos para o locus microssatélite ILSTS005 encontrados na raça Nelore. 


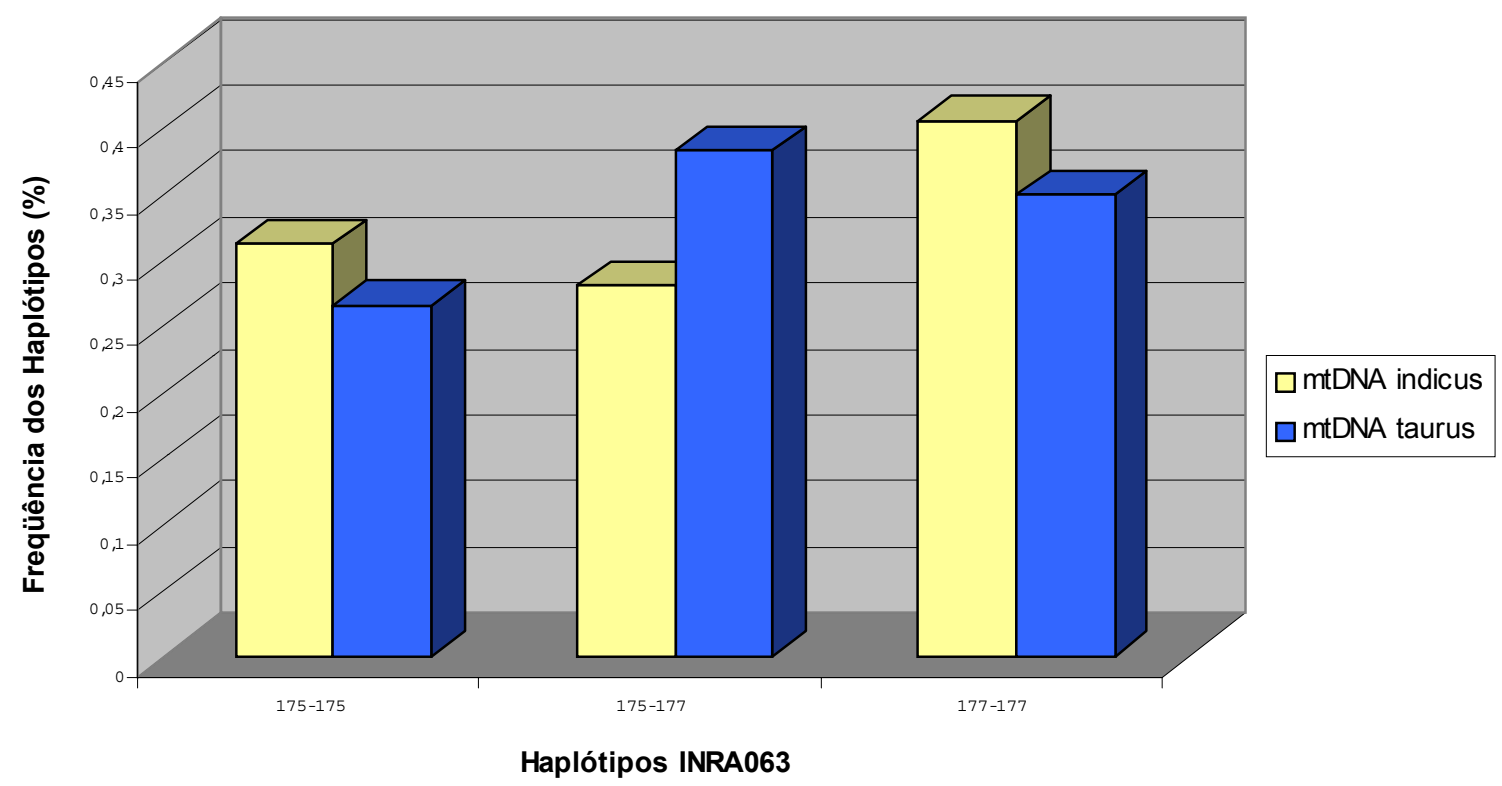

FIGURA 18 - Haplótipos para o locus microssatélite INRA063 encontrados na raça Nelore.

Em geral, o Equilíbrio de Hardy-Weinberg foi observado para quatro dos cinco microssatélites, sendo que apenas o locus INRA063 não se encontra em equilíbrio, desta maneira, os demais testes estatísticos foram realizados excluindo-se este microssatélite, como apresentado nas TABELAS 10, 11, 12 e 13. 
TABELA 10 - Resultados da variância por locus em cada população.

\begin{tabular}{ccccc}
\hline População & Locus & Variância & $\begin{array}{c}\text { Média dos } \\
\text { alelos }\end{array}$ & $\begin{array}{c}\text { Tamanho da } \\
\text { amostra }\end{array}$ \\
\hline \multirow{4}{*}{ Europeus } & ETH225 & 43,45 & 146,87 & 16 \\
& HEL1 & 12,20 & 107,75 & 16 \\
& HEL9 & 15,71 & 155,12 & 16 \\
& ILSTS005 & 0,80 & 185,50 & 16 \\
\hline \multirow{2}{*}{ Nelore } & ETH225 & 55,75 & 153,89 & 78 \\
mtDNA indicus & HEL1 & 12,11 & 107,64 & 68 \\
& HEL9 & 11,41 & 155,18 & 66 \\
& ILSTS005 & 7,75 & 186,66 & 78 \\
\hline \multirow{2}{*}{ Nelore } & ETH225 & 60,06 & 153,78 & 130 \\
mtDNA taurus & HEL1 & 11,34 & 107,58 & 116 \\
& HEL9 & 10,74 & 155,23 & 118 \\
& ILSTS005 & 4,63 & 185,81 & 120 \\
\hline
\end{tabular}

TABELA 11 - Valores de RHO e P para os componentes de variância nas três populações analisadas.

\begin{tabular}{ccc}
\hline Populações & RHO & $\mathrm{P}$ \\
\hline Europeus X mtDNA indicus & 0,225 & 0,013 \\
Europeu X mtDNA taurus & 0,217 & 0,011 \\
mtDNA indicus X mtDNA taurus & $-0,006$ & 0,686
\end{tabular}

Para $\mathrm{P} \leq 0,05, \mathrm{RHO} \neq 0$ 
TABELA 12 - Valores de RHO e P para os loci microssatélites nas três populações analisadas.

\begin{tabular}{ccc}
\hline Populações & RHO & P \\
\hline Europeus X mtDNA indicus & 0,089 & 0,016 \\
Europeu X mtDNA taurus & 0,056 & 0,031 \\
mtDNA indicus X mtDNA taurus & 0,002 & 0,219 \\
\hline
\end{tabular}

Para $\mathrm{P} \leq 0,05, \mathrm{RHO} \neq 0$

TABELA 13 - Valores de distância genética $(\delta \mu)^{2}$ para as populações analisadas.

\begin{tabular}{cc}
\hline Populações & $(\delta \mu)^{2}$ \\
\hline Europeus X mtDNA indicus & 12,672 \\
Europeu X mtDNA taurus & 11,970 \\
mtDNA indicus X mtDNA taurus & 0,185 \\
\hline
\end{tabular}

Os valores encontrados nas análises para os componentes de variâncias de $\mathrm{RHO}$ nas populações e entre os loci microssatélites apontam para diferenças significativas entre as raças européias (Holandeses, Ayrshire, Piemontês, Limousin e Aberdeen Angus) e a raça Nelore, tanto para a população mtDNA indicus como mtDNA taurus. O que de fato era esperado já que dados de distância genética apontam estas duas populações, europeus e zebuínos, como grupos distintos, o que pode ser observado nos valores de distância genética $(\delta \mu)^{2}$ obtidos neste estudo (Figura 19). 


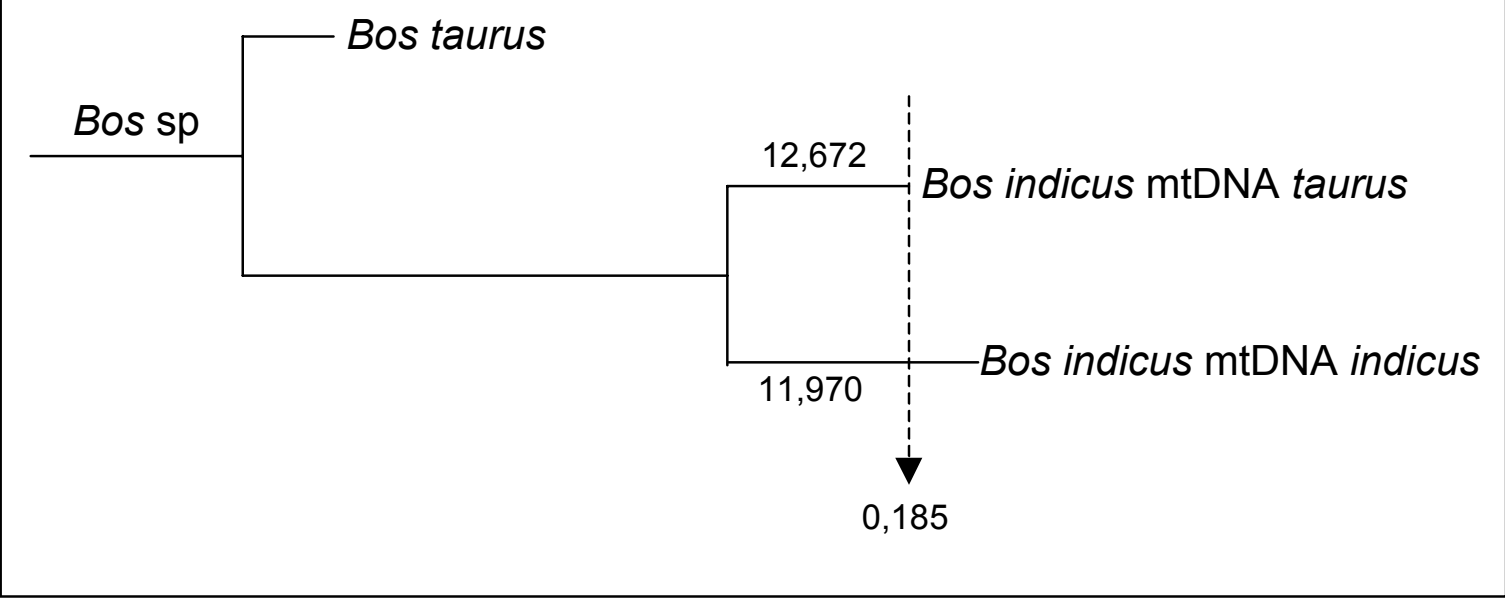

FIGURA 19 - Dendograma criado a partir dos dados de distância genética calculados dos microssatélites ETH225, HEL1, HEL9 e ILSTS005 para a população de Europeus e Nelore mtDNA taurus e indicus.

Em alguns casos, como observado para os componentes de variância entre as populações taurus e indicus da raça Nelore, o RHO apresentou um valor negativo o que significa que a maioria dos componentes de variância está dentro das populações analisadas e não entre as populações.

Os valores obtidos com o cálculo do $\mathrm{RHO}$ estimam a variância para todos os loci microssatélites sem considerar aqueles que são Bos taurus ou Bos indicus específicos. Este tipo de estimativa é efetivo quando se compara distância entre populações que se diferenciaram por mutações ao acaso após um evento de isolamento geográfico, entretanto, não serve para isolamento de hibridização como foi proposto neste estudo (MacHugh et al., 1997). Desta forma, calculou-se a diferença da freqüência dos alelos reconhecidamente Bos taurus e Bos indicus específicos. A diferença média encontrada foi de 4,08\% com exceção dos microssatélite ILSTS005 em que esta diferença esteve em torno de $14 \%$. 
Quando calculada a média da freqüência dos alelos zebu-específicos dos loci ETH225, HEL1 e ILSTS005 para população Nelore, cálculo semelhante ao realizado por MacHugh et al. (1997), foi obtido o valor de 6,12\%. Este valor indica uma participação de aproximadamente $6 \%$ de Bos taurus no rebanho Nelore estudado.

\subsection{DNA Satélite 1711b}

DNA satélites são encontrados no genoma dos eucariotos em quantidades variáveis de seqüências repetitivas, por volta de 10\% em mamíferos. Sendo assim, o fragmento amplificado do satélite $1711 \mathrm{~b}$ bovino, é oriundo de várias cópias de uma repetição de 1023pb presentes no genoma e que pode apresentar variações em parte de suas repetições decorrentes de mutação ou recombinações (Lewin, 2000; Stephan, 1986).

Nestes casos, como explicado por Lewin (2000), a perda do sítio de restrição em parte das seqüências repetitivas pode gerar dímeros, trímeros ou tetrâmeros semelhantes ao fragmento monomérico. Durante os experimentos foi amplificada parte do DNA satélite $1711 \mathrm{~b}$ contendo $875 \mathrm{pb}$.

Durante os trabalhos com RFLP, não foi possível detectar o sítio para a enzima Sau3A ou Mbo I como sugerido por Nijman e Lenstra (1999), assim como não foi possível encontrar variações no nucleotídeo após o seqüenciamento (Nijman et al., 2001). A ausência deste sítio impossibilitou a estimativa individual da taurindicinização como proposto inicialmente. Todavia, o fragmento amplificado foi seqüenciado e os resultados obtidos apontam a presença de polimorfismo nos sítios de restrição da enzima Msp I (Figura 20). 


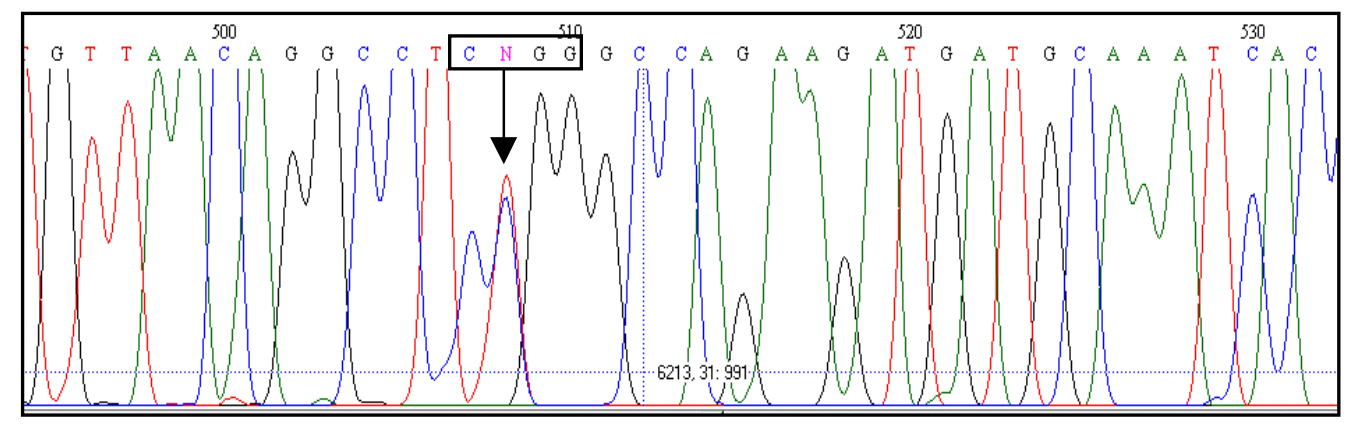

FIGURA 20 - Eletroferograma do DNA Satélite seqüenciado a partir do fragmento do DNA amplificado pela PCR. O quadro indica o sítio de restrição da enzima Msp I em um animal portador do padrão de restrição $A B$. $A$ seta indica o nucleotídeo polimórfico.

O DNA satélite apresentou três padrões de digestão distintos para animais Nelore que podem ser observados na Figura 21a. Verifica-se que o polimorfismo presente em animais da raça Nelore pode ser gerado pela presença de um sítio de restrição da enzima Msp I homogeneamente distribuído em todos os fragmentos satélites, dois sítios de restrição homogeneamente distribuído em todos os fragmentos satélites ou os dois padrões de restrição heterogeneamente distribuídos.

Os animais das raças européias (Holandês, Aberdeen Angus, Ayrshire, Limousin, Piemontês e Charolês) apresentaram sempre o padrão de digestão $B$, característico de dois sítios de restrição distribuídos homogeneamente no satélite 1711b (Figura 21b). Os três possíveis genótipos estavam presentes em ambas populações de Nelore (Figura 21a).

O sítio de restrição descrito no Genbank ocorre no nucleotídeo 524 do fragmento amplificado (Streeck, 1982). Os dados do sequenciamento, e as análises dos RFLPs demonstram a ausência do sítio de restrição no nucleotídeo 524 em parte das seqüências Bos indicus analisadas, bem como a 
existência de um sítio adicional no nucleotídeo 121 do fragmento amplificado em todos os animais analisados. Este sítio não é encontrado na seqüência descrita por Streeck (1982) depositadas no Genbank, porém encontra-se presente em seqüências no zebu e no europeu como descrito por Nijman e Lenstra (2001) e verificado neste estudo.

A ausência do sítio de restrição da enzima $M s p$ I, devido a mutação C/T no nucleotídeo 524 do fragmento amplificado é comum somente a animais Bos indicus como mostram as Figuras 20 e 21a.
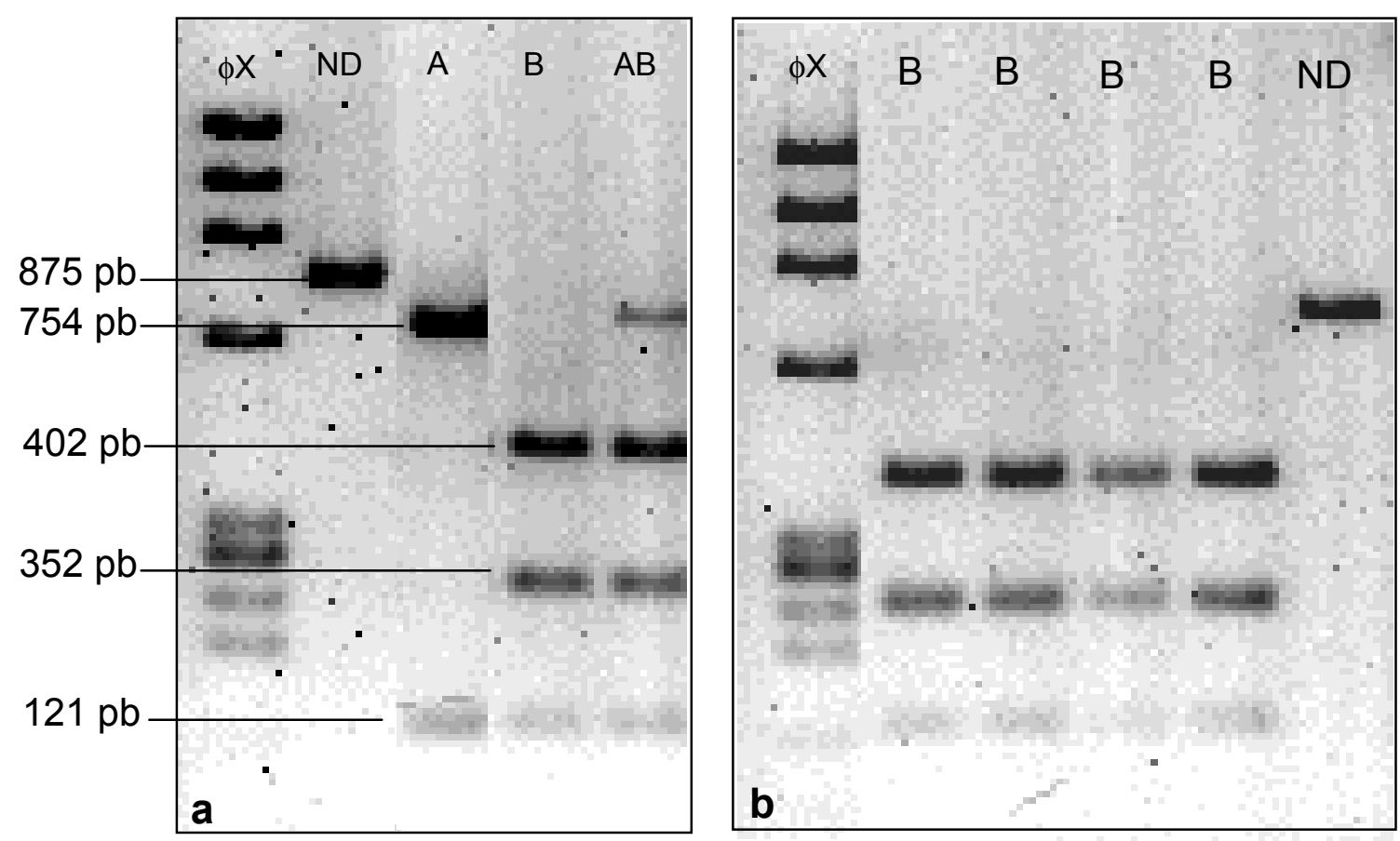

FIGURA 21 - Genótipos encontrados para o DNA Satélite 1711b após digestão com a enzima Msp I. Figura 21a representa animais da raça Nelore e a figura $21 \mathrm{~b}$ representa animais europeus. 
A Tabela 14 relaciona os dados encontrados pelos autores acima mencionados com os obtidos neste trabalho.

TABELA 14 - Presença (+) ou ausência (-) do sítio de restrição para a enzima Msp I no DNA satélite $1711 \mathrm{~b}$ em animais taurinos e zebuínos.

\begin{tabular}{ccccccc}
\hline $\begin{array}{c}\text { Sítio de } \\
\text { restrição }\end{array}$ & Genbank & \multicolumn{2}{c}{$\begin{array}{c}\text { Nijman e Lenstra } \\
(2000)\end{array}$} & \multicolumn{2}{c}{$\begin{array}{c}\text { Resultados deste } \\
\text { trabalho }\end{array}$} \\
\hline Nucleotídeo & Seqüência consenso & B. taurus & B. indicus & B. taurus & B. indicus \\
\hline 121 & - & + & + & + & + \\
524 & + & + & + & + & + e/ou - \\
\hline
\end{tabular}

A análise de variância comparando a freqüência dos genótipos $A, B$ ou $A B$ observados no DNA satélite sugere ausência de diferença nas populações Nelore estudadas. Entretanto, a freqüência do padrão de restrição $B$, comum em todos animais Bos taurus, foi maior nos animais portadores de mtDNA taurus (Figura 22). Isto corrobora com os resultados obtidos com os fragmentos microssatélites, mostrando uma diferença de $6 \%$ da freqüência dos padrões de restrição indicus específicos no mtDNA taurus comparado ao mtDNA indicus, um valor próximo aos $6,12 \%$ obtido com os alelos específicos nos três microssatélites. 


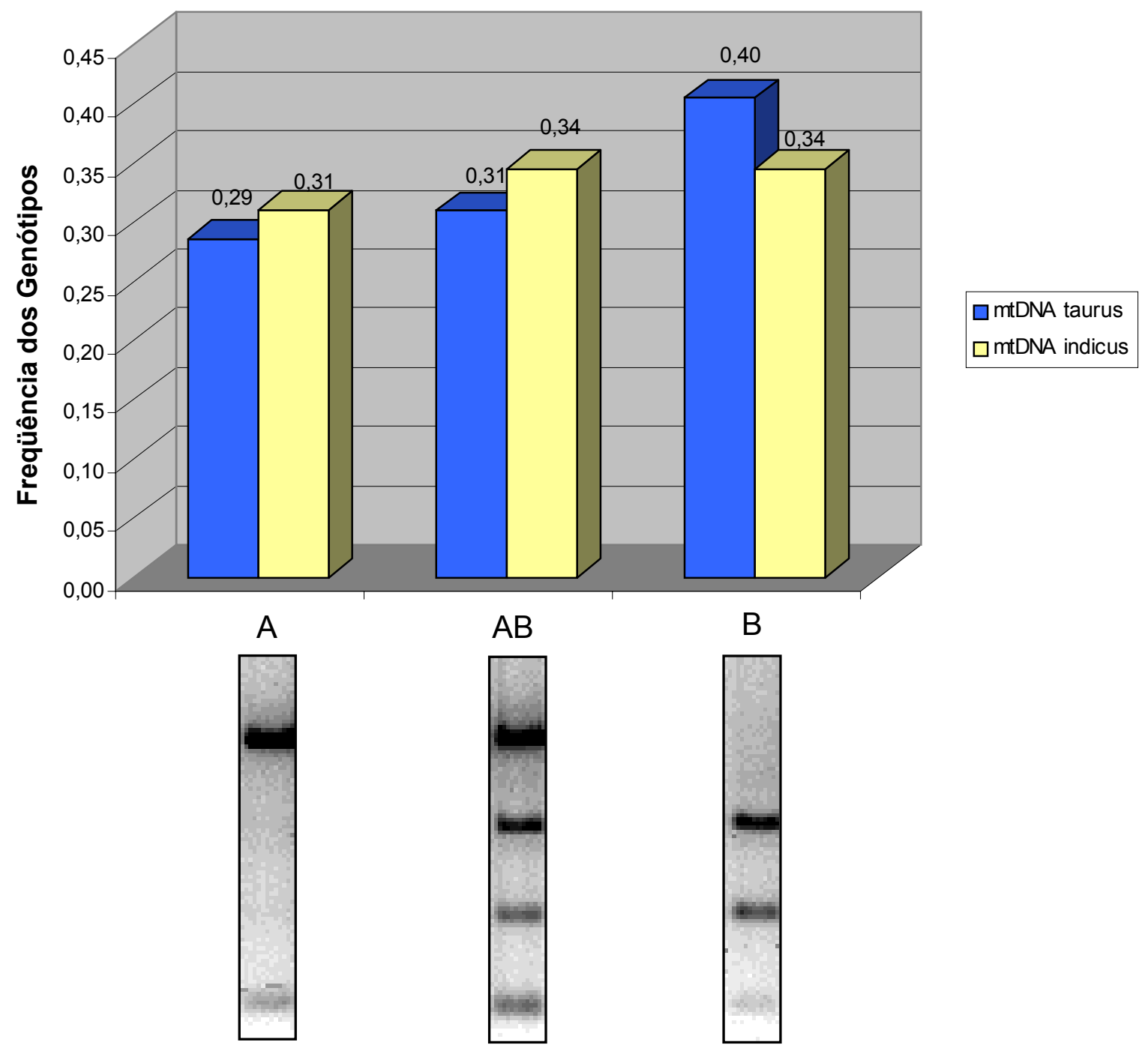

FIGURA 22 - Freqüência dos genótipos encontrados para o DNA Satélite $1711 b$ após digestão com a enzima Mspl. 
A estimativa de taurindicinização em populações de bovinos mediante a comparação da freqüência de alelos microssatélites Bos indicus específicos foi realizada anteriormente em bovinos europeus e zebus africanos (MacHugh et al., 1997). A estimativa da participação de Bos taurus nas populações de zebuínos africanas variou de 40 a 17\%.

Os resultados sugeridos neste estudo com metodologia semelhante indicam um grau de hibridização de aproximadamente $6 \%$, estimadas tanto pelos marcadores microssatélites quanto satélite. Esta estimativa, embora ainda inicial, sugere um "grau de sangue" de aproximadamente 15/16, coerente com a aparência fenotípica Nelore.

O genoma humano possui aproximadamente 50.000 genes (Lander et al., 2001), sendo assim, o grau de taurindicinização calculada neste trabalho equivale a aproximadamente 3.000 genes em um animal ou números muito maiores segregando na população.

$\mathrm{Na}$ ausência de seleção, teoricamente em uma população com 117.600 animais teremos representado pelo menos uma cópia de cada gene de origem de animais Bos taurus distribuídos aleatoriamente, desta forma, levando-se em consideração que a população de Nelore registrado ultrapassa o número de 457.000 animais em reprodução (Magnabosco et al., 1997) o uso do melhoramento animal pode auxiliar a selecionar qualquer gene originado do Bos taurus ligado a aumento da produção e eliminar genes introgredidos indesejáveis.

Comparativamente, o genoma humano possui em torno de 2,7 bilhões de nucleotídeos, e o DNA satélite $1711 \mathrm{~b}$ do bovino, é responsável por $7,1 \%$ do seu genoma (Macaya et al., 1978). Os números mencionados acima equivalem a 191.700.000 nucleotídeos ou 187.390 cópias do satélite bovino.

Este grande número de cópias e a existência de recombinação reportada anteriormente (Stephan, 1986) sugerem os polimorfismos DNA satélite como excelentes marcadores para eventos de hibridização. Todavia, não foi possível encontrar um marcador Bos taurus específico neste trabalho. O marcador 
indicus específico descrito (uma mutação C-T no nucleotídeo 524) serviu para estimar a participação de Bos taurus em uma população de Bos indicus. Um estudo interessante seria estimar a contribuição do zebu, demonstrada pelo cromossomo Y (Giovambattista et al., 2000), em animais da raça Caracu e Mocho nacional (raças adaptadas "nacionais").

As estimativas realizadas acima se referem a animais puros de origem e pertencentes aos rebanhos de elite nacionais. Esta amostragem pode não ser representativa do rebanho anelorado, que constitui a grande maioria do rebanho nacional. 


\section{CONCLUSÕES}

As análises realizadas neste trabalho demonstram que os marcadores satélites e microssatélites podem ser bastante informativos quando se trata da diferenciação de populações distintas, por exemplo zebus de taurinas.

As estimativas apresentadas, embora preliminares, sugerem um grau de hibridização de aproximadamente $6 \%$, estimadas tanto pelos marcadores microssatélites quanto satélite e coerente com a aparência fenotípica dos animais.

Foi possível identificar um marcador satélite Bos indicus específico que auxiliou na estimativa da contribuição Bos taurus na população zebuína. Este marcador poderá ser utilizado em estudos que visam estimar a contribuição zebuína em raças taurinas.

A freqüência de taurindicinização reportada neste trabalho, sugere o uso do melhoramento animal visando a selecionar genes Bos taurus que sofreram introgressão ligados a aumento da produção e eliminar genes introgredidos indesejáveis.

\section{PERSPECTIVAS}

Futuros estudos aumentando o número de marcadores zebu-específicos e o número da amostragem tornarão possível uma melhor estimativa da participação de Bos taurus na raça Nelore.

Uma variação da metodologia utilizada para análise do DNA satélite 1711b, visando minimizar o efeito dos heterodímeros, poderá permitir a estimativa da contribuição da taurindicinização em animais de raças taurinas adaptadas. 


\section{REFERÊNCIAS BIBLIOGRÁFICAS}

ALBERTS, B.; BRAY, D.; LEWIS, J.; RAFF, M.; ROBERTS, K.; WATSON, J. D. Molecular biology of the cell. 3 ed. New York: Garland Pub., c1994. 1294 p.

ALMEIDA, S. E. M.; MACHADO, M. S. N.; STEIGLEDER, C. S.; GAMA, C. L.; HUTZ, M. H.; HENKES, L. E.; MORAES, J. C. F.; WEIMER, T. A. Genetic diversity in a Brazilian bovine herd basead on four microsatellite loci. Genetics and Molecular Biology, v. 23, n. 2, p. 347-350, 2000.

ANDERSON, S. ; BANKER, A.T.; BARREL, B. G.; DE BRUIJIN, M. H. L.; COULSON, A. R.; DROUIN, J.; EPERON, L. C.; NIERLICH, D. P.; ROE, B. A.; SANGER, F.; SCHREIER, P. H.; SMITH, A. J. H.; STADENM, R.; YONG, L. G. Sequence and organization of the human mitochondrial genome. Nature, v. 290, p. 457-465, 1981.

ANDERSON, S. ; DE BRUIJIN, M. H. L.; COULSON, A. R.; EPERON, L. C.; SANGER, F.; YONG, L. G. Complete sequence of bovine mitochondrial DNA, conserved features of the mitochondrial genome. Jornal of Molecular Biology, v. 156, p. $683-717,1982$.

BERIDZE. Satellite DNA. Berlin/Heidelberg Germany: Springer-Verlag, 1986.

BISHOP, M. D. et al. A genetic linkage map for cattle. Genetics, v. 136, p. 619639, 1994.

BRADLEY, D. G.; MACHUGH, D. E.; CUNNINGHAM, E. P; LOFTUS, R. T. Mitochondrial diversity and the origins of African and European cattle. Proceedings of the National Academy of Science, USA, v. 93, p. 5131-5135, 1996. 
BRADLEY, D. G.; LOFTUS, R. T.; CUNNINGHAM, E. P.; MACHUGH, D. E. Genetic and domestic cattle origins. Evolutionary Anthropology, v.6, p. 79-86, 1998.

BRADLEY, D. G.; CUNNINGHAM, E. P. Genetic aspects of domestication. In: FRIES, R.; RUVINSKY, A. (Ed.) The genetics of cattle Wallingford: CABI Publishing, 1999. cap. 2, p. 15-31.

BREZINSKY, L. ILSTS005: a plymorphic bovine microsatellite. Animal Genetics, v.24, p. 73, 1993.

BROWN, W. M.; GEORGE, M.; WILSON, A. C. Rapid evolution of animal mitochondrial DNA. Proceedings of the National Academy of Science, USA, v. 76, p. 1967-1971, 1979.

BRUTLAG, D. L. Molecular arrangement and evolution of heterochromatic DNA. Annual Reviews Genetic, v. 14, p. 121-144, 1980.

CHARLESWORTH, B.; SNLEGOWSKI, P.; STEPHAN, W. The evolutionary dynamics of repetitive DNA in eukaryotes. Nature, v. 371, p. 215-220, 1994.

CHINNERY, P. F.; TURNBULL, D. M. Mitochondrial DNA mutations in the pathogenesis of human disease. Molecular Medicine Today, v. 6, n. 11, p. 425432, 2000.

CHOO, K. H. A. Centromerization. Trends in Cell Biology, v. 10, p. 182-188, 2000.

CSINK, A. K.; HENIKOFF, S. Something from nothing: the evolution and utility of satellite repeats. Trends in Genetics, v. 14, n. 5, p. 200-204, 1998.

CORRENS, C. Vererbungsversuche mit blass (gelb) grünen und buntblattrigen Sippen bei Mirrabilis, Urtica, und Lunaria. Zeit Vererbungsl , v.1, p. 291-329, 1909.

CUMMINS, J. Mitochodrial DNA in mammalian reproduction. Reviews of reproduction, v. 3, p. 172-182, 1998. 
DOOLITTLE, W. F.; SAPIENZA, C. Selfish genes, the phenotype paradigm and genome evolution. Nature, v. 284, n. 5757, p. 601-603, 1980.

EPSTEIN, H. Origin of the domestic animals of Africa. New York, NY, USA: Africana Publishing Cooperation, 1971. $1 \mathrm{v}$.

EPSTEIN, H.; MASON, I. L. Cattle. In: animals. New York: Longman, 1984. p. 6-27. . Evolution of domesticated

ESTOUP, A. L.; GARNERY, M.; SOLIGNA, C. ; CORNUET, J. M. Microsatellite variation in honey-bee (Apis mellifera L.) populations: hierarchical geneticstructure and test of the infinite allele and stepwise mutation models. Genetics, v. 140, n. 2, p. 679-695, 1995.

FRIES, R.; EGGEN, A.; STRANZINGER, G. The bovine genome contains polymorphic microsatellites. Gemonics, v. 8, p. 403-406, 1990.

FRIES, R.; EGGEN, A.; WOMACK, J. E. The bovine genome map. Mammalian Genome, v. 4, p. 405-428, 1993.

GEORGES, M. et al. DNA fingerprinting in domestical animals using four diferent minisatellite probes. Cytogenetics and Cell Genetics, v. 47, p. 127-131, 1988.

GILES, R. E. et al. Maternal inheritance of human mitochondrial DNA.

Proceedings of the National Academy of Science, USA, v.77, p. 6715-6719, 1980.

GIOVAMBATTISTA, G. et al. Male-mediated introgression of Bos indicus genes into Argentine and Bolivian Creole cattle breeds. Animal Genetics, v.5 p. 302-305, 2000.

GOLDSTEIN, D. B. et al. Genetic absolute dating based on microsatellites and origin of modern humans. Proceedings of the National Academy of Science, USA, v.96, p. 6720-6727, 1995.

GOODMAN, S. J. RST CALC: A collection of computer programs for calculating estimates of genetic differentiation from microsatellite data and determining their significance. Molecular Ecology, v.6, p.881-885, 1997. 
GROVES, C. P. Systematic relationships in the Bovini (Artiodactyla, Bovidae). Zeitschrift für Zoologische Systematik und Evolutionsforschung, v. 19, p. 264-278, 1981.

GUÉRIN, G. et al. Further characterization of a somatic cell hybrid panel: ten new assignments to the bovine genome. Animal Genetics, v. 25, p. 31-35, 1994.

HALL, S. J. G.; BRADLEY, D. G. Conserving livestock breed biodiversity. Tree, v. 10, n. 7, p. $267-270,1995$.

HAMADA, H.; PETRINO, M.; KAKUNAGA, T. A novel repeated element with ZDNA. Proceedings of the National Academy of Science, USA, v. 79, p. 64656469, 1982.

HANOTTE, O. et. al. A polymorphic $Y$ chromosome microsatellite locus in cattle. Animal Genetics, v. 8, p. 308-322, 1997.

HIRAOKA, J., HIRAO, Y. Fate of sperm tail components after incorporation into the hamster egg. Gamete Research, v. 19, p. 369-380, 1988.

HUTCHINSON, C. A. et al. Maternal inheritance of mammalian mitochondrial DNA. Nature, v. 251, p. 536-538, 1974.

JARNE, P.; LAGODA, P. J. L. Microsatellites, from molecules to populations and back. Tree, v. 11, p. 424-429, 1996.

JEFFREYS, A. J., WILSON, V.; THEIN, S. L. Hypervariable minisatellite regions in the human DNA. Nature, v. 314, p. 67-73, 1985.

KAPPES, S. M. et al. A second-generation linkage map of the bovine genome. Genome Research, v. 7, p. 235-249, 1997.

KAUKINEN, J.; VARVIO, S. L. Eight polymorphic bovine microsatellites. Animal Genetics, v. 24, p. 148, 1993. 
KELLY, T. J.; SMITH, H. O. A restriction enzime from Haemophilus influenzae. IIbase sequence of the recognition site. Journal of Molecular Biology, v. 51, p. 393-409, 1970.

KEMP, S. J. et al. A panel of polymorphic bovine, ovine and caprine microsatellite markers. Animal Genetics, v. 26, p. 299-306, 1995.

KIEFFER, N. M.; CARTWRIGTH, T. C. Sex chromosome polymorphism in domestic cattle. Journal of Heredity, v. 59, p. 35-6, 1968.

$\mathrm{KOCH}$. Neocentromeres and alpha satellite: a proposed structural code for functional human centromere DNA. Human Molecular Genetics, v. 9, p. 149-154, 2000.

KOPECKA, H; MACAYA, G.; CORTADAS, J.; THIÉRY, J-P.; BERNARDI, G. Restriction enzyme analysis of satellite DNA components from the bovine genome. European Journal of Biochemistry, v. 84, p. 189-195, 1978.

LANDER, E.S. et al. Initial sequencing and analysis of the human genome. Nature, v. 409, p. 860-921, 2001.

LEWIN, B. Genes VII. Oxford: Oxford University Press, 2000. 989 p.

LIPCHITZ, L.; AXEL, R. Restriction endonuclease cleavage of satellite dna in intact bovine nuclei. Cell, v. 9, n. 2, p. 355-364, 1976.

LITT, M.; LUTY, J. A. A hypervariable microsatellite revealed by in vitro amplification of a dinucleotide repeat within the cardiac muscle actin gene. American Journal of Human Genetics, v. 44, p. 397-401, 1989.

LOFTUS, R. T. et al. Evidence for two independent domestications of cattle. Proceedings of the National Academy of Science of the United States of America, v. 91 , p. $2757-2761,1994 a$.

LOFTUS, R. T. et al. Mitochondrial genetic variation in European, African, and Indian cattle populations. Animal Genetics, v. 25, p. 265-271, 1994b. 
MACAYA, G.; CORTADAS, J.; BERNARDI, G. Analysis of bovine genome by density-gradient centrifugation - preparation of dg+dc-rich dna components European Journal Biochemistry, v. 84, n. 1, p. 179-188, 1978.

MACHUGH, D. E.; SHRIVER, M. D., LOFTUS, R. T.; CUNNINGHAM, P.; BRADLEY, D. G. Microsatellite DNA variation and the evolution, domestication and phylogoegraphy of taurine an Zebu cattle. Genetics, v. 146, p. 1071-1086, 1997.

MAGNABOSCO, C. de U. et al. Catálogo de linhagens do germoplasma zebuíno: raça Nelore. Brasília: embrapa-Cenargen, 25 p. 1997.

MANWELL, C.; BAKER, C. M. A. Chemical classification of cattle: 2. phylogenetic tree and specific status of the Zebu. animal and blood groups. Biochemical Genetics, v. 11, p. 151-162, 1980.

MARTÍN-BURRIEL, I.; GARCÍA-MURO, E.; ZARAGOZA, P. Genetic diversity análisis of six Spanish native cattle breeds using microsatellites. Animal Genetics, v. 30, p. 177-182, 1999.

MEIRELLES, F.V. et al. Is the American Zebu is really Bos indicus? Genetics and Molecular Biology, v. 22, n. 4, p. 543-547, 1999.

MIESFELD, R.; KRYSTAL, M; ARNHEIM, N. A member of new repeated sequence family wich is conserved throughout eucaryotic evolution is found between the human $\delta$ - and $\beta$-globulin genes. Nucleic Acids Research, v. 9, p. $5931,1981$.

MOAZAMI-GOUDARZI, K.; LALOË, D.; FURET, J. P.; GROSCLAUDE, F. Analysis of genetic relationships between 10 cattle breeds with 17 microsatellites. Animal Genetics, v. 28, p. 338-345, 1997.

MOXON, E. R.; WILLIS, C. DNA Microsatellites: agents of evolution? Scientific American p. 72-77, 1999.

MULLIS, K. B. The unusual origin of the polimerase chain reaction. Scientific American, v. 262, p. 6-42, 1990. 
NEI, M. Molecular evolutionary genetics. Columbia University Press, New York. 1987. $1 \mathrm{v}$.

NIJMAN, I. J. et al. Satellite DNA polymorphisms and AFLP correlate with Bos indicus-taurus hybridization. Animals Genetics, v. 30, p. 265-273, 1999.

NIJMAN, I. J.; LENSTRA, J. A. Mutation and recombination in cattle satellite DNA: a feedback model for the evolution of satellite DNA repeats. Journal of Molecular Evolution, v. 52, p. 361-371, 2001.

NOWAK, R. M. Walker's mammals of the world. 5. ed. Baltimore, MD: John Hopkins University Press, 1991. 1 v.

PAYNE, W. J. A. Domestication: a forward step in civilization. In: HICKMAN, C.G. (Ed.). Cattle Genetic Resources. Amsterdam: Elsevier, 1991. p. 51-72.

PECH, M.; STREECK, R. E.; ZACHAU, H. G. Patchwork structure of a bovine satellite DNA. Cell, v. 8, p. 883-893, 1979.

PEGORARO, L. et al. Sequence comparison of mitochondrial tRNA denes and origen of light strand replication in Bos taurus and Nellore (Bos indicus) breeds. Animal Genetics, v. 27, p. 91-94, 1996.

PŁUCIENNICZACK, A.; SKOWROSKI, J.; JAWORSKI, J. Nucleotide sequence of bovine 1.715 satellite DNA and its relation to other bovine satellite sequences. Journal Molecular Biology, v. 158, p. 293-304, 1982.

PÖSCHL, E.; STREECK, R. E. Prototype sequence of bovine 1.720 satellite DNA. Journal Molecular Biology, v. 143, p. 147-153, 1980.

RITZ, L. R.; GLOWATZKI-MULLIS, M. L.; MACHUGH, D. E.; GAILLARD, C. Phylogenetic analysis of the tribe Bovini using microsatellites. Animal Genetics, v. 31, p. 178-185, 2000.

SAMBROOK, J.; RUSSEL, D. W. Molecular cloning: a laboratory manual. New York, NY, USA: Cold Spring Harbour Laboratory Press, 2001. 
SANTIAGO, A. A. Gado Nelore: 100 anos de seleção. São Paulo: Editora dos Criadores, 1987.

SANTIAGO, A. A. História do zebu. In: O gado Nelore. São Paulo: Instituto de Zootecnia, 1972. p. 69-196.

SANTIAGO, A. A. O Nelore. São Paulo: Instituto de Zootecnia, 1960. 451 p.

SANTOS, R. O Zebu. Uberaba: Agropecuária Tropical, 1998. 856 p. (Edição comemorativa dos 60 anos de registro genealógico).

SCHLÖTTERER, C.; TAUTZ, D. Slippage synthesis of simple sequence DNA. Nucleic Acids Research, v. 20, p. 211-215, 1992.

SHITARA, H.; HAYASHI, J. I.; TAKAHAMA, S.; KANEDA, H.; YONEKAWA, H. Maternal inheritance of mouse mtDNA in interspecific hybrids: segregation of the leaked paternal mtDNA followed by the prevention of subsequent paternal leakage. Genetics, v. 148, p. 851-857, 1998.

SLATKIN, M. A measure of population subdivision based on microsatellite allele frequencies [published erratum appears in Genetics 1995 Mar;139(3):1463]. Genetics, v.139, p. 457, 1995.

STEFFEN, P. et al. Isolation and mapping of polymorphic microsatellites in cattle. Animal Genetics, v. 24, p. 121-124, 1993.

STEPHAN, W. Recombination and evolution of satellite DNA. Genetic Research. v. 47, p. $167-174,1986$.

STREECK, E. R. A multicopy insertion sequence in the bovine genome with structural homology to the long terminal repeats of retroviruses. Nature, v. 298, p. 767-769, 1982.

STREECK, E. R. Inserted sequences in bovine satelite DNA`s. Science, v. 213, p. $443-445,1981$. 
TAMBASCO, D. D. et al. Evidência de alelo nulo para um loco microssatélite em uma amostra de Nelore. Genetics and Molecular Biology v.23, n.3 suppl. 260-261, 2000.

TAPAROWSKY, E. J.; GERBI, S. A. Structure of $1711 \mathrm{~b} \mathrm{gm} / \mathrm{cm}^{3}$ bovine satellite DNA: evolutionary relationship to satellite I. Nucleic Acids Research, v. 10, p. 5503-5515, 1982.

TAUTZ, D. Hypervariability of simple sequences as a general source for polymorphic DNA markers. Nucleic Acids Research, v. 17, p. 6463-6471, 1989.

VAIMAN, D. et al. A set of 99 cattle microsatellites: characterisation, synteny mapping, and polymorphism. Mammalian Genome, v. 5, p. 288-297, 1994.

VIACAVA, C.; CASTANHO FILHO, E. P.; PIRES, G.; JOSAHKIAN, L. A.; BARBOSA JÚNIOR, N. S.; PINEDA, N.; FELÍCIO, P. E.; LÔBO, R. B. L. Nelore: o boi ecológico que está conquistando o mundo. São Paulo: Peirópolis, 2000. $107 \mathrm{p}$.

WALL, D. A.; DAVIS, S. K.; READ, B. M. Phylogenetic relationship in the subfamily Bovinae (Mammalia: artiodactyla) based on ribosomal DNA. Journal of Mammalogy, v. 73, p. 262-275, 1992.

WARING, M.; BRITTEN, R. J. Nucleotide sequence repetition - a rapidly reassociating fraction of mouse DNA. Science, v. 154, p. 791, 1966.

WEBER, J.; MAY, P. E. Abundant class of human DNA polymorphisms which can be typed using the polymerase chain reaction. American Journal of Human Genetics, v. 44, p. 388-396, 1989.

WILLARD, H. F. Centromeres: the missing link in the development of human artificial chromosomes. Current Opinion in Genetic Development, v. 8, p. 219225, 1998.

ZHANG, Y. et al. Five polymorphic bovine microsatellite loci: IDVGA-62A, IDVGA-71, IDVGA-82, IDVGA-88, IDVGA-90. Animal Genetics, v. 26, p. 365367, 1995. 